Linköping Studies in Science and Technology, Dissertation No. 1938

\title{
Lean Remanufacturing:
}

\section{Reducing Process Lead Time}

Jelena Kurilova-Pališaitienè

Department of Management and Engineering

Linköping University, SE-581 83 Linköping, 2018 
(C) Jelena Kurilova-Pališaitienė 2018

Linköping Studies in Science and Technology, Dissertation No. 1938

ISBN: 978-91-7685-303-0

ISSN: 0345-7524

Printed by: LiU-Tryck, Linköping

Distributed by:

Linköping University

Department of Management and Engineering

SE-581 83 Linköping, Sweden

Tel: +4613 281000, fax: +4613281873 


\title{
Lean Remanufacturing: \\ Reducing Process Lead Time
}

\author{
By \\ Jelena Kurilova-Pališaitienė \\ June 2018 \\ ISBN 978-91-7685-303-0 \\ No. 1938 \\ ISSN 0345-7524
}

Keywords: Circular Economy, Lean Production, Toyota Production System, Value Stream Mapping, Remanufacturing Process Challenges and Improvements, Process Efficiency

Department of Management and Engineering

Linköping University

SE-581 83 Linköping, Sweden

iii 


\section{ABSTRACT}

Remanufacturing is a product recovery option in which used products are brought back into useful life. While the remanufacturing industry stretches from heavy machinery to automotive parts, furniture, and IT sectors, it faces challenges. A majority of these challenges originate from the remanufacturing characteristics of having little control over the core (the used product or its part), high product variation, low production volumes, and a high proportion of manual work, when compared to manufacturing. Some remanufacturing challenges appear to be process challenges that prolong process lead time, making remanufacturing process inefficient.

Lean is an improvement strategy with roots in the manufacturing industry. Lean helps to increase customer satisfaction, reduce costs, and improve company's performance in delivery, quality, inventory, morale, safety, and other areas. Lean encompasses principles, tools and practices to deal with e.g. inefficient processes and long process lead times. Therefore, in this thesis lean has been selected as an improvement strategy to deal with long remanufacturing process lead time.

The objective of this thesis is to expand knowledge on how lean can reduce remanufacturing process lead time. This objective is approached through literature studies and a case study conducted at four remanufacturing companies. There are five challenges that contribute to long process lead time: unpredictable core quality, quantity, and timing; weak collaboration, information exchange, and miscommunication; high inventory levels; unknown number of required operations in process and process sequence; and insufficient employee skills for process and product upgrade. When analysing the case companies' process lead times, it was found that there is a need to reduce waiting times, which account for 95 to 99 per cent of process lead times at three of the four companies.

To improve remanufacturing process efficiency and reduce remanufacturing process lead time six lean practices are suggested: product families; kanban; layout for continuous flow; cross functional teams; standard operating procedures; and supplier partnerships. The suggested lean practices have a key focus on reducing waiting time since it prolongs the process lead time.

This thesis contributes to lean remanufacturing research with the case study findings on lean practices to reduce remanufacturing process lead time and increase process efficiency. 


\section{SAMMANFATTNING}

Återtillverkning är ett sätt att ta hand om använda produkter så att de kommer till ny användning. Återtillverkningsindustrin sträcker sig idag över många branscher, allt ifrån stora maskiner, bildelar, möbler till elektronik. Återtillverkning har många olika utmaningar där en majoritet av dessa kommer från att återtillverkningsindustrin har låg kontroll över stommar (använda produkter som är tänkta att återtillverkas), stor produktvariation, låga produktionsvolymer, och en hög andel manuellt arbete, i jämförelse med vanlig tillverkning. En del av dessa utmaningar är processutmaningar som förlänger ledtiden för processen och gör återtillverkningsprocessen ineffektiv.

Lean är en förbättringsstrategi som har sina rötter inom tillverkningsindustrin. Lean hjälper till att öka kundnöjdhet, minska kostnader och förbättra företagens prestanda när det gäller bl.a. leverans, kvalitet, lager, moral och säkerhet. Lean inbegriper principer, verktyg och arbetssätt för att t.ex. hantera ineffektiva processer och långa ledtider. I denna avhandling har därför lean valts som en förbättringsstrategi för att hantera utmaningarna med långa ledtider inom återtillverkningsprocesser.

Syftet med avhandlingen är att utöka kunskapen om hur lean kan användas för att minska ledtider inom återtillverkningsprocesser. Syftet uppnås genom litteraturstudier samt en fallstudie hos fyra återtillverkare. De fem processutmaningar som bidrar till långa ledtider inom återtillverkningsprocesserna är: oförutsägbar kvalitet, kvantitet och leverans av stommar; svagt samarbete, informationsutbyte och kommunikation; höga lagernivåer; okänt antal nödvändiga processteg och $i$ vilken ordning de ska utföras; samt otillräckliga kunskaper hos personal angående processer och produktuppgraderingar. Under företagsanalysen framkom det att det fanns ett stort behov av att minska väntetider inom återtillverkningsprocesserna. Väntetiderna uppgick till 95-99 procent av processledtiderna hos tre av de fyra fallföretagen som studerats.

För att förbättra effektiviteten i återtillverkningsprocesserna och minska ledtiderna inom återtillverkningsprocesserna föreslås följande sex leanarbetssätt: produktfamiljer; kanban; layout för kontinuerliga flöden; tvärfunktionella lag; standardiserade arbetssätt; och bättre samarbete med underleverantörer. De föreslagna leanarbetssätten fokuserar på att minska väntetider eftersom det främst är dessa som bidrar till att förlänga ledtiderna hos återtillverkningsprocesserna.

Avhandlingen bidrar till forskningen på lean återtillverkning genom resultaten från fallstudierna om hur leanarbetssätt kan minska ledtider hos återtillverkningsprocesser samt förbättrar dessas effektivitet. 


\section{ACKNOWLEDGMENTS}

I want to express my warm thanks to my academic supervisors, industrial partners, my University colleagues and, of course, family and friends for supporting my research work with thoughtful assistance and advice.

First of all, I would like to express my gratitude to my supervisor, Associate Professor Erik Sundin, for his strong support and guidance throughout the planning and development of this doctoral thesis. Also, thanks to my other supervisor, Associate Professor Bonnie Poksinska, for her extensive and valuable insights and recommendations during my doctoral thesis. I would also like to thank Professor Mats Björkman for sharing his valuable time to enhance the quality of this thesis.

My very special thanks to the case company managers for their open communication and guidance during the data collection sessions, and especially to the employees, who participated in the focus group interviews and shared their valuable perception of the studied issues.

I must also acknowledge my University colleagues whose profound feedback and encouragement motivated me to accomplish this thesis.

My most sincere gratitude to my husband Justinas, daughter Katrina and my family in Lithuania, who stayed enthusiastic and provided needed support through the development of this thesis.

Thanks also to the numerous friends for their sincere support in accomplishing this thesis.

In conclusion, I want to thank VINNOVAs research program, called "Strategiska Innovationsområden”, for providing financial assistance for this research.

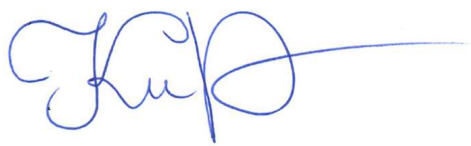

Jelena Kurilova-Pališaitienė

Linköping, June 2018 


\section{APPENDED PAPERS}

PAPER I Kurilova-Palisaitiene J. and Sundin E. (2014). Challenges and Opportunities of Lean Remanufacturing. International Journal of Automation Technology, vol. 8 (5), pp. 644-652.

PAPER II Kurilova-Palisaitiene J. and Sundin E. (2014). Minimum Time for Material and Information Flows Analysis at a Forklift Truck Remanufacturer. Proceedings of $6^{\text {th }}$ Swedish Production Symposium (SPS14). Göteborg, Sweden, September 16-18.

PAPER III Kurilova-Palisaitiene J. and Sundin E. (2015). Toward Pull Remanufacturing: A Case Study on Material and Information Flow Uncertainties at a German Engine Remanufacturer. Procedia CIRP, $12^{\text {th }}$ Global Conference on Sustainable Manufacturing - Emerging Potentials, vol. 26, pp. 270-275.

PAPER IV Kurilova-Palisaitiene J. and Sundin E. (2017). Remanufacturing Lead Time Reduction through Just-in-Time Lean Strategy: A Case Study on Laptops. Proceedings of $3^{\text {rd }}$ International Conference on Remanufacturing (ICOR17). Linköping, Sweden, October 24-26, pp. 61-69.

PAPER V Kurilova-Palisaitiene J., Sundin E., and Poksinska B. (2017). Lean Improvements in Remanufacturing: Solving Information Flow Challenges. Proceedings of $20^{\text {th }}$ Quality Management and Organizational Development (QMOD) Conference. Elsinore, Denmark, August 5-7.

PAPER VI Kurilova-Palisaitiene J., Lindkvist L., and Sundin E. (2015). Towards Facilitating Circular Product Life Cycle Information Flow via Remanufacturing. Procedia CIRP, $22^{\text {nd }}$ CIRP Conference on Life Cycle Engineering, vol. 29, pp. 780-785.

PAPER VII Kurilova-Palisaitiene J., Sundin E., and Poksinska B. (2018). Remanufacturing Challenges and Possible Lean Improvements. Journal of Cleaner Production, vol. 172, pp. 3225-3236. 


\section{AUTHOR's CONTRIBUTION TO THE PAPERS}

Jelena Kurilova-Palisaitiene is the main author of all appended papers. She identified the research gap, developed the papers' ideas, and wrote the major part of each paper. She was the key author responsible for correcting final versions of the manuscripts for publication in scientific journals (Paper I and Paper VII) and conference proceedings (Papers II-VI). The co-authors contributed with feedback and suggested improvements.

PAPER I Jelena Kurilova-Palisaitiene conducted the literature study. She collected and analyzed the data.

PAPER II Jelena Kurilova-Palisaitiene conducted the case study. She developed and applied the empirical data collection method described in section 2.3.1.

PAPER III Jelena Kurilova-Palisaitiene conducted the case study. She applied an improved empirical data collection method and analyzed the data.

PAPER IV Jelena Kurilova-Palisaitiene conducted the case study and analyzed the data.

PAPER V Jelena Kurilova-Palisaitiene conducted the case study and analyzed the data.

PAPER VI Jelena Kurilova-Palisaitiene analyzed, compared and aligned the data collected at three case companies and wrote the second part of the paper (Section 3). Louise Lindkvist contributed with her empirical data and wrote the first part of the paper (Section 2).

PAPER VII Jelena Kurilova-Palisaitiene conducted the literature study and the case study. She analyzed, compared and aligned the data collected at four case companies with theory from the literature study. Bonnie Poksinska and Erik Sundin contributed with feedback and active participation in reviewing several versions of the manuscript. 


\section{OTHER PUBLICATIONS}

i. Kurilova-Palisaitiene J. and Sundin E. (2013). Remanufacturing: Challenges and Opportunities to be Lean. In Proceedings for the $8^{\text {th }}$ International Symposium on Environmentally Conscious Design and Inverse Manufacturing (EcoDesign 2013). Jeju Island, South Korea, December 4-6.

ii. Kurilova-Palisaitiene J. and Sundin E. (2015). Lean Remanufacturing: Addressing System Challenges. In Proceeding for the $9^{\text {th }}$ International Symposium on Environmentally Conscious Design and Inverse Manufacturing (Eco-Design). Tokyo, Japan, December 2-4.

iii. Kurilova-Palisaitiene, J., Permin E., Mannheim T., Buhse K., Schmitt, R., Corves, B., and Björkman, M. (2016). Industrial Energy Efficiency Potentials: An Assessment of Three Different Robot Concepts. International Journal of Sustainable Engineering, vol. 10 (3), pp. 1-12.

\section{Licentiate thesis}

Kurilova-Palisaitiene J. (2015). Toward Lean Remanufacturing: Challenges and Improvements in Material and Information Flows. Licentiate thesis no. 1718, Department of Management and Engineering, Linköping University, June 10. 


\section{TABLE OF CONTENTS}

1. INTRODUCTION ……...................................................................................................

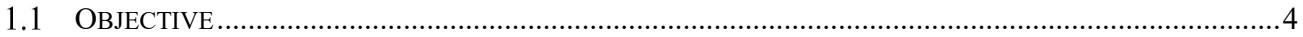

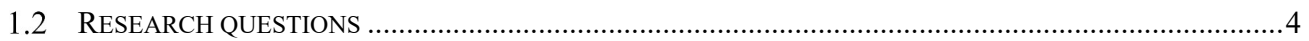

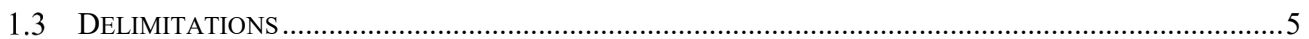

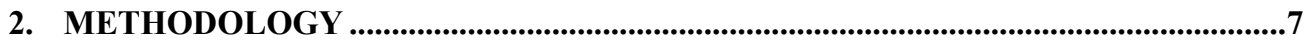

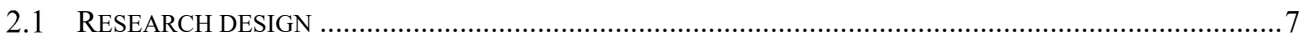

2.2 LITERATURE STUDY .........................................................................................

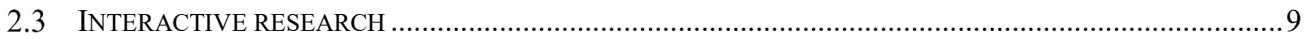

2.4 VALIDITY, RELIABILITY AND GENERALIZABILITY …………………………………………... 13

3. THEORETICAL BACKGROUND …………………......................................................15

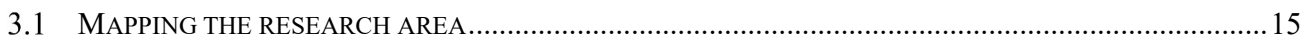

3.2 LEAN

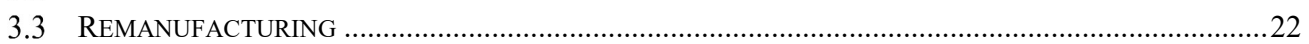

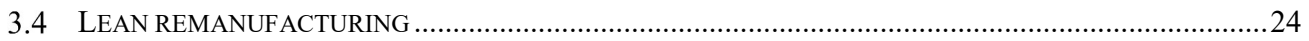

4. PROCESS LEAD TIME CHALLENGES WITHIN REMANUFACTURING ............27

4.1 REMANUFACTURING PROCESSES AT THE CASE COMPANIES.......................................................27

4.2 REMANUFACTURING PROCESS LEAD TIME …………………………………..........................35

4.3 REMANUFACTURING PROCESS CHALLENGES THAT PROLONG PROCESS LEAD TIME ……….............37

5. LEAN PRACTICES TO ADDRESS REMANUFACTURING PROCESS LEAD

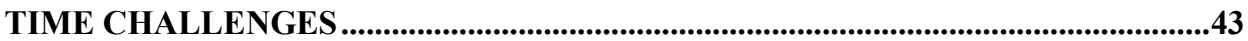

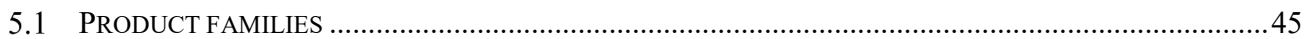

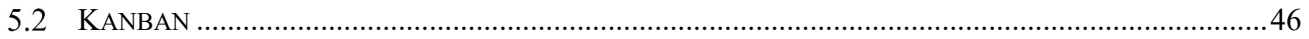

5.3 LAYOUT FOR CONTINUOUS FLOW............................................................................................4

5.4 CROSS FUNCTIONAL TEAMS …………………………………………………………...48

5.5 STANDARD OPERATING PROCEDURES ………………………………………………......49

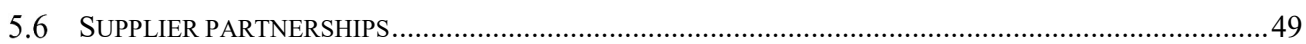

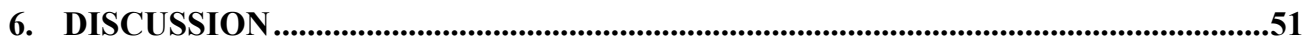

6.1 PROCESS LEAD TIME CHALLENGES WITHIN REMANUFACTURING ……………………………......51

6.2 LEAN PRACTICES TO ADDRESS REMANUFACTURING PROCESS LEAD TIME CHALLENGES ...............53

6.3 REFLECTION ON THE RESEARCH METHOD …………………………………………….......5

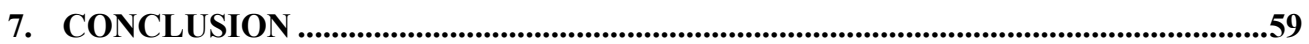

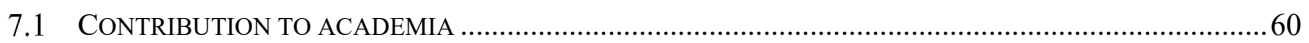

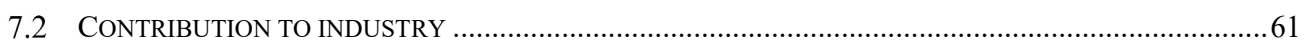

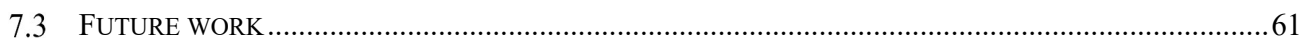

REFERENCES ....................................................................................................................63

APPENDED PAPEPS

APPENDIX

APPENDIX A: QUESTIONNAIRE TO THE CASE COMPANIES

APPENDIX B: INTERVIEW QUESTIONS TO THE CASE COMPANIES

APPENDIX C: IMPROVEMENT SQUARE 


\section{LIST OF FIGURES}

FIGURE 1: CIRCULAR ECONOMY FOR TECHNICAL MATERIALS. .2

FIGURE 2: THE FIVE RESEARCH PHASES AND SEVEN APPENDED PAPERS OF THIS THESIS PUT ON A TIMELINE 8

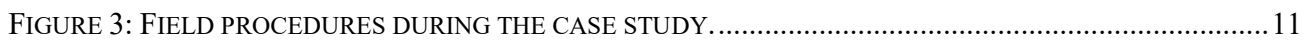

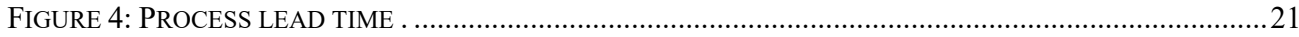

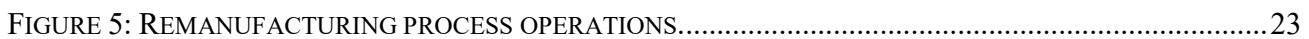

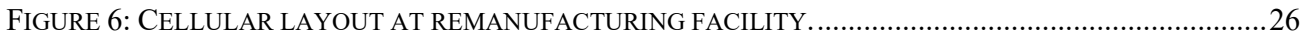

FIGURE 7: REMANUFACTURING PROCESS AND LEAD TIME SYMBOLS USED IN THIS THESIS.....................29

FIGURE 8: PROCESS OPERATIONS AND PROCESS LEAD TIME AT COMPANY A …….................................30

FIGURE 9: PROCESS OPERATIONS AND PROCESS LEAD TIME AT COMPANY B ...........................................31

FIGURE 10: PROCESS OPERATIONS AND PROCESS LEAD TIME AT COMPANY C .......................................32

FIGURE 11: PROCESS OPERATIONS AND PROCESS LEAD TIME AT COMPANY D..........................................33

FIGURE 12: PROCESS LEAD TIME DISTRIBUTION AT CASE COMPANIES. ................................................. 35

FIGURE 13: THREE LEVELS OF REMANUFACTURING CHALLENGES FROM THE LITERATURE STUDY .........38

FIGURE 14: A POSSIBLE TRANSITION FROM CORE PRODUCT FAMILY TO REMANUFACTURED PRODUCT

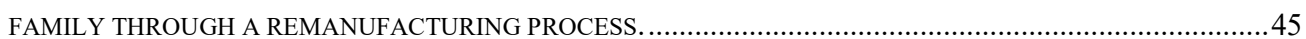

FIGURE 15: TWO TYPES OF LATE PRODUCT PULL FROM CORE INVENTORY: DOWN GRADE AND UPGRADE

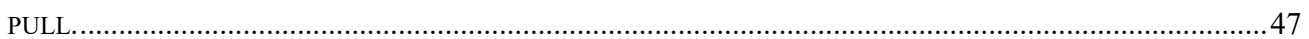

FIGURE 16: CELLULAR LAYOUT FOR REMANUFACTURING PROCESS OPERATIONS. ................................48 FIGURE 17: RELATION BETWEEN REMANUFACTURING CHARACTERISTICS AND PROCESS CHALLENGES THAT PROLONG PROCESS LEAD TIME .52 


\section{LIST OF TABLES}

TABLE 1: RELATION BETWEEN RQS AND THE APPENDED PAPERS. 9

TABLE 2: THE STRATEGIES USED TO ENSURE RESEARCH VALIDITY, RELIABILITY AND GENERALIZABILITY.

TABLE 3: FORMS OF WASTE, VARIABILITY AND INFLEXIBILITY ACCORDING TO LEAN. . .17

TABLE 4: MOST COMMON LEAN TOOLS AND PRACTICES FOR IMPROVEMENTS AT OPERATIONAL LEVEL. 18

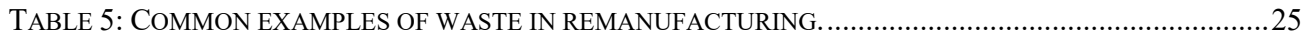

TABLE 6: OVERVIEW OF COMPANIES' CHARACTERISTICS.....................................................................28

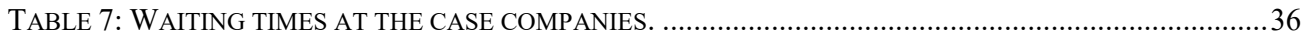

TABle 8: CROSS CASE ANALYSIS OF REMANUfACTURING PROCESS LEVEL CHALLENGES THAT CAUSE LONG LEAD TIMES, IDENTIFIED AT EACH COMPANY.

TABLE 9: LEAN PRACTICES TO ADDRESS REMANUFACTURING PROCESS CHALLENGES THAT PROLONG REMANUFACTURING PROCESS LEAD TIME . .44

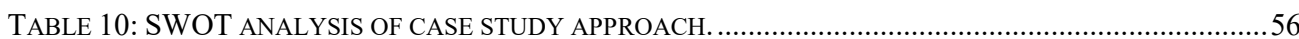




\section{TERMS AND ABBREVIATIONS}

BOM

CE

Challenge

Core

Core acquisition

Core inventory

CR

ERN

FIFO Lanes

Filling machine

Finished goods inventory

Inventory

IR

Kanban
Bill of material - is a comprehensive list of parts, assemblies, and other materials required to create a product (Bicheno and Holweg, 2009).

Circular Economy - Restorative and regenerative by design, which aims to keep products, components and materials at their highest utility and value at all times (Ellen MacArthur Foundation, 2013).

A task or situation that tests someone's abilities. A synonym for problem, difficult task, test, trial (en.oxforddictionaries.com).

Previously used product or its part (Steinhilper, 1998).

The buying or obtaining of a product or its parts intended for remanufacturing (adapted from en.oxforddictionaries.com; Steinhilper, 1998 and Sundin, 2006).

Inventory at the beginning of the remanufacturing process (adapted from en.oxforddictionaries.com).

Contracted Remanufacturer - companies that are contracted to remanufacture products on behalf of other companies (Lund, 1983).

European Remanufacturing Network, initially a project, funded by Horizon 2020 to understand the shape of remanufacturing in the EU, now an integrated information sharing platform for EU remanufacturers (adopted from www.remanufacturing.eu).

First In First Out Lanes - are dynamic buffers of inventory between operations having different cycle times (Bicheno and Holweg, 2009).

A machine that fills a container or package with liquid food or beverage (adapted from en.oxforddictionaries.com).

Inventory at the end of the remanufacturing (in this thesis) process (adapted from en.oxforddictionaries.com).

Goods in stock (en.oxforddictionaries.com).

Independent Remanufacturer - companies that remanufacture products with little or no contact with the OEM, and that need to buy or collect cores for their process (Lund, 1983).

Kanban is a material ordering system that can be used as a main production control tool (Morgan and Liker, 2006). Kanban refers to a 
system of triggering mechanisms that synchronizes process pace with real consumer demand (Liker, 2004).

Lean

MRP

Non-value-added operation

OEM

OER

Partly waiting

time

Process efficiency

Process lead time

Stakeholder of

Circular

Economy

Supermarket

Technical

material

Throughput

Time for operations
An improvement strategy that was originally used to boost manufacturers' performance (Womack et al., 2007).

Material Requirements Planning - a production planning, scheduling, and inventory control system to support manufacturing processes (Groover, 2008).

Also known as non-value-added activity, is activity that does not generate any value for the customer. This activity is treated as a waste that has to be minimized or eliminated (Bicheno and Holweg, 2009).

Original Equipment Manufacturer - companies with a control over product development and production of their products (Lund, 1983).

Original Equipment Remanufacturer - companies that remanufacture their own products (Lund, 1983).

The combination of the time for operations and waiting time due to difficulties in separation (e.g., in this thesis, Case Company D).

The ratio of useful work performed in a process to the total work (en.oxforddictionaries.com). In this thesis, process efficiency denotes the ratio of the time for value-added operations to the process lead time.

The time between the initiation and completion of a production process (en.oxforddictionaries.com). In this thesis, lead time refers to the time from core arrival to shipment to the customer.

Interested party or member of the Circular Economy, such as: Product designer, Supplier, OEM, Retailer, Customer, Maintenance, Remanufacturers, Recyclers.

An inventory store which is refilled as soon as the needed part has been collected (Bicheno and Holweg, 2009).

Raw materials, resources, components, products and cores within the industrial process loop in the Circular Economy diagram, separated from organic materials (adapted from Ellen MacArthur Foundation, 2013).

The amount of material or items passing through a system or process (en.oxforddictionaries.com).

Time used to perform both value-added and non-valued-added operations (Bicheno and Holweg, 2009). 
TPS

Unavoidable waiting time

Value

Value-added operation

VSM

Waiting at inventory

Waiting for order Waiting for incoming order (material and/or information) on core or spare part.

Waiting time

Waste

WIP inventory

Toyota Production System - a production system, developed by Taiichi Ohno, comprises management philosophy and practices to organize manufacturing and logistics for the automobile manufacturer, including interaction with suppliers and customers (Monden, 1983).

The waiting time at the core inventory, appearing due to remanufacturers having little control over the core. Unavoidable waiting time is a part of process lead time; however, it is eliminated from the calculation of process efficiency (in this thesis).

Processing that the customer is eager to pay for (Ohno, 1988).

Also known as value-added activity, denotes activity that generates value for the customer (Womack and Jones, 2007).

Value Stream Mapping - a mapping tool in lean, used to develop an overview of production operations, including material and information flow as well as connections to external stakeholders (Rother and Shook, 2003).

Waiting at core, WIP or finished goods inventory.

The time spent in waiting (waiting at inventory or for order, as in this thesis), presented as a proportion of the process lead time minus time for operations (Bicheno and Holweg, 2009).

Everything that does not add value (Pascal, 2002) or activities that do not generate any value that the end customer is not willing to pay for (Slack, Chambers, and Johnston, 2010).

Work-in-progress inventory - inventory in between process operations during the remanufacturing process (in this thesis) (adapted from en.oxforddictionaries.com). 


\section{INTRODUCTION}

This chapter elaborates upon the significance of remanufacturing to the Circular Economy. The aim of this introduction is to lay the foundations for the objective and research questions of the thesis. Thesis delimitations are also formulated.

In 2015, Steffen et al. (2015) introduced the notion of planetary boundaries to emphasize the need for many countries around the world to base their economies on renewable resources. The issue of resource depletion is critical due to the rapidly increasing consumption of energy and material resources (UN, 2015). In 2015 United Nations (UN, 2015) declared that if the global population reaches 9.6 billion by 2050, our planet's natural resources would not be enough to sustain the current lifestyles. For this reason, in 2012 the European Union (EU) was already emphasizing an urgent need to move to a resource-efficient and, ultimately, a regenerative Circular Economy (CE) (Manifesto for a Resource Efficient Europe, 2012).

A CE can be defined as "Restorative and regenerative by design, and which aims to keep products, components and materials at their highest utility and value at all times" (Ellen MacArthur Foundation, 2013). As shown in Figure 1, in a CE, products are developed, manufactured, used, and recovered to reduce the amount of lost materials (leakage) and prevent the extraction of virgin and scarce raw materials. Consequently, a CE maintains its resources within a closed system, providing a viable solution for raw material recovery loops: first maintenance and repair, followed by reuse/redistribution, then refurbishment/ remanufacturing, and material recycling (Ellen MacArthur Foundation, 2013). 


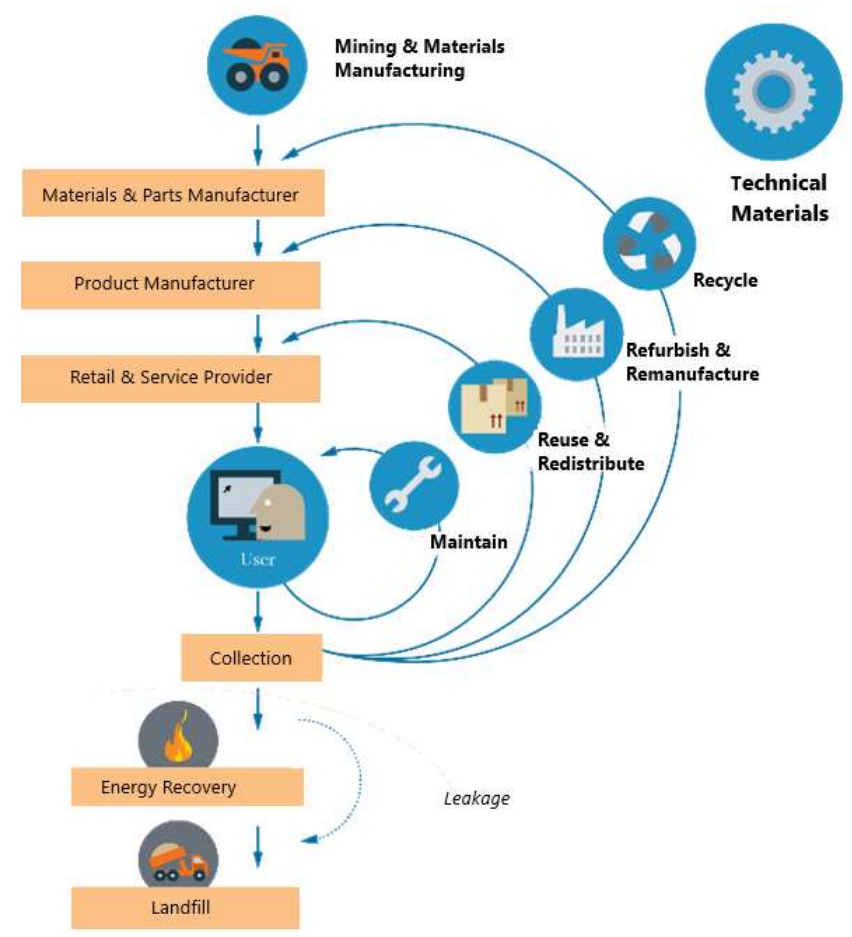

Figure 1: Circular Economy for technical materials (adapted from Ellen MacArthur Foundation, 2013).

Remanufacturing is an important part of a CE, which brings cores (previously used products and their parts) to like-new or better performance (Steinhilper, 1998; CRR, 2007; Östlin et al., 2008), and hence back into useful life (APSRG, 2014). To maintain efficient remanufacturing loops in a CE (see Refurbish and Remanufacture loop in Figure 1), an efficient remanufacturing process is required. To meet the need for a more efficient remanufacturing process, the process lead time becomes a critical issue (Östlin et al., 2009). Consequently, a shorter remanufacturing process lead time generates a more efficient remanufacturing loop, making it economically possible to remanufacture more products (Parker et al., 2015).

Today, remanufacturing is established in various industries, such as heavy transport, automotive, industrial machines and tools, electronics and IT, furniture, and consumer goods. It contributes to dramatic savings in raw materials, energy and water resources compared with new product manufacturing (Sundin and Lee, 2011) and offers business opportunities to various stakeholders within the CE (Östlin et al., 2008; APSRG, 2014). In Europe alone, the remanufacturing industry is estimated to generate billions of euros annually. According to an ERN report, by 2030 EU remanufacturing could attain an 
annual value of $€ 70 \mathrm{bn}$, with an associated increase in employment of 34,000 jobs (Parker et al., 2015).

At the same time, remanufacturing requires complex industrial processes due to the high number of uncertainties related to core quality, quantity and timing (Guide, 2000; Lundmark et al., 2009). The quality of the core for remanufacturing is determined by the previous user's industry, utilization purpose and intensity. The issues of insufficient core quality and quantity are supplemented by the lack of information on core condition and length of time with the previous user. Unknown quantity and timing of the core is the result of an ineffective and unsynchronized core return process (Guide, 2000). Additionally, remanufacturing maintains little control over the core, higher product variation, lower production volumes, and a higher proportion of manual work, when compared to manufacturing (Steinhilper, 1998; Guide, 2000; Seitz and Peattie, 2004). These four characteristics cause the majority of the remanufacturing process challenges that prolong process lead time, making remanufacturing process inefficient. An inefficient remanufacturing process restricts the number of remanufactured products available to the next user in the CE (Parker et al., 2015). To maintain remanufacturing as an efficient part of the $\mathrm{CE}$, its process lead time needs to be reduced.

Process lead time is a typical Key Performance Indicator (KPI) at manufacturing companies that apply lean to their operations (Bicheno and Holweg, 2009). According to Duggan (2002), lead time is the time from a spare part or product enters the process line until it exits process line. Ahlstrom (1997) defines lead time as one of the most dangerous source of process challenge, since a long lead time can conceal problems. Consequently, long remanufacturing process lead time could be an indicator for possible process challenges at remanufacturing.

Lean production (or simply lean, used in this thesis), originating from the Toyota Production System (TPS), is one possible improvement strategy to address remanufacturing process challenges and reduce process lead time. Lean is a well-spread improvement strategy that was originally used to boost manufacturers' performance (Womack et al., 2007) while pursuing five goals: shortest lead time, best quality, lowest cost, best safety and highest employee morale (Liker, 2004; Womack et al., 2007; Shah and Ward, 2007). To meet these five goals, lean delivers a set of principles, tools and practices that help to solve process issues, gain operational efficiency, and increase productivity (Fullerton et al., 2003; Shah and Ward, 2007).

While lean production has been successfully used by manufacturing companies (Fullerton et al., 2003), few studies have shown how lean can help to address remanufacturing process challenges, especially in terms of reducing process lead time. Some researchers have identified the potential to apply lean to remanufacturing facilities or have even observed the positive effects of lean application; for example: Jacobs and Chase (2001), Fargher (2006), Sundin (2006), Östlin and Ekholm (2007), Hunter and Black (2007), Kucher (2008) and Kanikula and Koch (2011). Pawlik et al. (2013) consider the 
combination of lean with remanufacturing to be a plausible methodology for increasing remanufacturing process efficiency. Thanks to lean remanufacturing researchers' findings and the positive effect on manufacturers' performance in terms of reducing process lead time, lean is considered a possible improvement strategy for addressing remanufacturing process challenges to reduce process lead time and improve process efficiency.

\subsection{OBJECTIVE}

The objective of this thesis is to expand knowledge on how lean can reduce remanufacturing process lead time.

\subsection{RESEARCH QUESTIONS}

Due to the remanufacturing characteristics the remanufacturing process lead time is considered to be longer than the manufacturing process lead time for the same type of product. However, today remanufacturing process faces many challenges, originating from the remanufacturing characteristics, that prolong process lead time and reduce remanufacturing process efficiency. Therefore, in order to increase remanufacturing process efficiency and reduce remanufacturing process lead time, it is important to identify the process challenges for remanufacturing that prolong process lead time.

\section{RQ1: What are the process challenges for remanufacturing that prolong process lead time?}

When the challenges behind long remanufacturing process lead time are identified, lean improvement strategy with its principles, tools and practices could be assessed regarding its capability to address the remanufacturing process challenges. The possibility to reduce remanufacturing process lead time using lean is studied for the second research question.

\section{RQ2: How can remanufacturing process challenges that prolong process lead time be addressed by lean?}

Lean improvement strategy for remanufacturing is not well-established, when compared to lean manufacturing research. This is partly due to remanufacturing process challenges, that appear to be different from the manufacturing ones. However, at the same time, remanufacturing process shares a lot of similarities with the manufacturing process. The possibility to study lean in remanufacturing context and, in particularly, to define how lean can reduce remanufacturing process lead time is undertaken in this thesis. The origin of the lean improvement strategy for remanufacturing is taken from lean manufacturing research. 


\subsection{DELIMITATIONS}

This thesis retains the inside out perspective and does not study remanufacturers' challenges from suppliers, customers or other stakeholders. Therefore, the scope of process challenges is restricted to the remanufacturing factory's boundaries; however, it includes receiving and sending out material and information beyond its limits. The focus of this thesis is further limited to the process challenges that prolong remanufacturing process lead time.

The lean improvement strategy for manufacturing is studied, ignoring lean strategy in other research areas, such as lean service or lean in processing industries. Philosophical and cultural aspects of lean strategy are not addressed in this thesis. 


\section{Methodology}

This methodological chapter depicts the way in which the research questions were approached. The research was carried out in five overlapping research phases, and the main research activities are outlined in chronological order.

In this chapter, an outline of the research design is followed by a description of the basis for the literature study and case study research. Within the case study, three data collection methods were applied to four remanufacturing companies: a questionnaire, observation and a focus group interview. The remaining body of this chapter covers the issues of research validity, reliability and generalizability.

\subsection{RESEARCH DESIGN}

The research design of this thesis encompasses five overlapping research phases (see Figure 2):

1) Theory phase aims to develop the necessary pre-understanding of the relevant issues in remanufacturing research (Campbell, 1975; Eisenhardt, 1989). To assist in targeting the research questions, a literature study on the topics of remanufacturing challenges and lean remanufacturing was conducted. This study provided insights into the studied topic and helped to define a pre-understanding of remanufacturing challenges and possible lean improvements in remanufacturing.

2) Field phase carries the case study to four remanufacturing companies. In order to further investigate the reasons for remanufacturing process challenges and define possible lean practices, the following data collection methods were applied to each 
case company: a questionnaire, observation and a focus group interview. Here, lead time and process efficiency issues are stressed in order to identify the causative challenges. The case study approach and data collection methods used to visualize and analyze remanufacturing challenges are described in Section 2.3.

3) Analysis and validation phase systematically studies the research findings: a) Remanufacturing challenges; b) Lean improvements to identified challenges, from the literature and case studies at four companies. Remanufacturing challenges collected from the literature and case studies are classified and analyzed. The research findings were validated at four companies.

4) Supplementary theory phase contributes with expanded knowledge on remanufacturing challenges and lean practices in order to address process leadtime challenges in manufacturing and remanufacturing. A second literature study was performed to find papers published after the first literature study in 2013.

5) Development phase enhances the thesis by matching possible lean improvements to remanufacturing process challenges. During this phase possible lean practices to address remanufacturing process challenges to reduce process lead time were evaluated and prioritized. A simplified generic research design in five phases is presented in Figure 2.

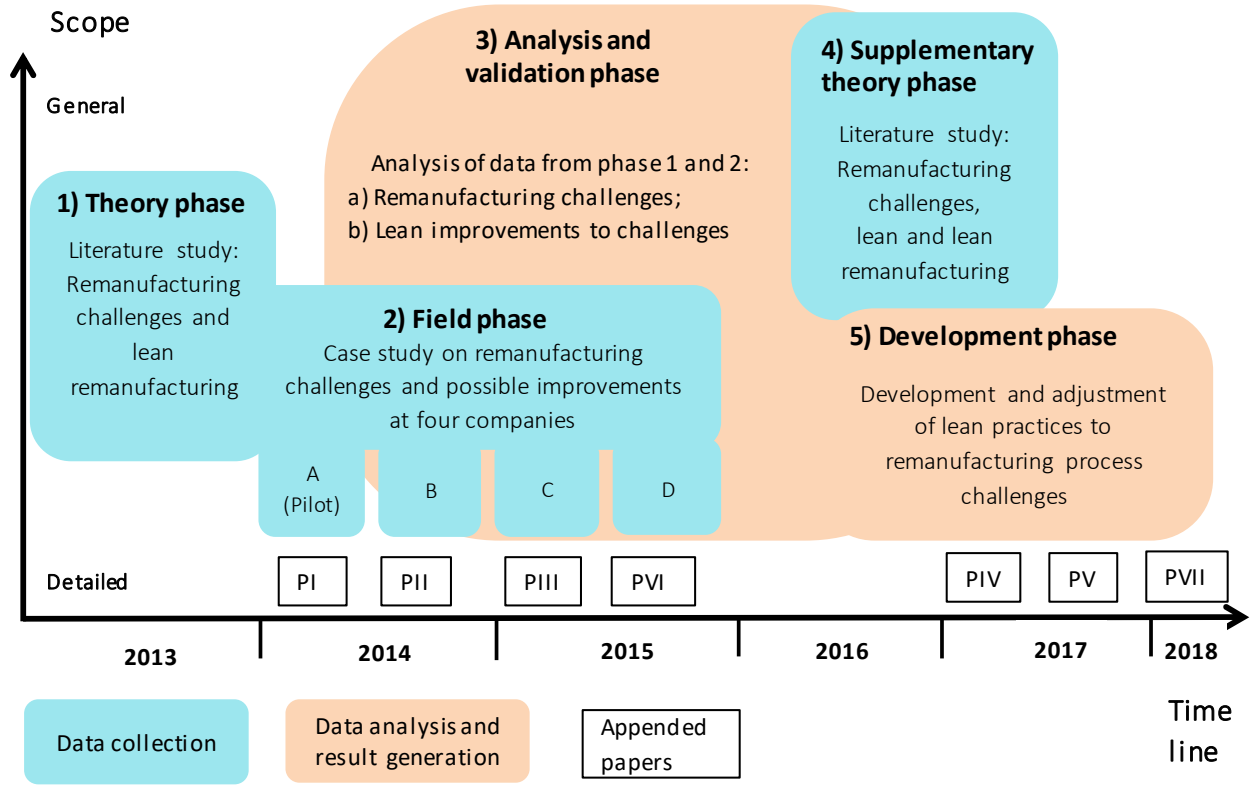

Figure 2: The five research phases and seven appended papers of this thesis put on a timeline. 
The research findings were also reflected in the appended papers that appear along the timeline in the order in which they were published. Table 1 shows the two research questions studied and analyzed in appended Papers I-VII, where RQ1 is reflected in every paper and RQ2 is covered in Papers IV, V and VII at most. At the same time, Paper I is based mainly on the literature study, while the rest of the papers combine both literature and case studies.

Table 1: Relation between RQs and the appended papers ( $\mathrm{x}$ - moderate focus, $\mathrm{X}$ - major focus).

\begin{tabular}{|l|c|c|c|c|c|c|c|}
\hline \multirow{2}{*}{ Research questions } & \multicolumn{7}{|c|}{ Appended papers } \\
\cline { 2 - 7 } & I & II & III & IV & V & VI & VII \\
\hline $\begin{array}{l}\text { RQ1: What are the process challenges for } \\
\text { remanufacturing that prolong process } \\
\text { lead time? }\end{array}$ & $\mathrm{X}$ & $\mathrm{X}$ & $\mathrm{X}$ & $\mathrm{X}$ & $\mathrm{X}$ & $\mathrm{X}$ & $\mathrm{X}$ \\
\hline $\begin{array}{l}\text { RQ2: How can remanufacturing process } \\
\text { challenges that prolong process lead time } \\
\text { be addressed by lean? }\end{array}$ & $\mathrm{x}$ & $\mathrm{x}$ & $\mathrm{X}$ & $\mathrm{X}$ & $\mathrm{X}$ & - & $\mathrm{X}$ \\
\hline
\end{tabular}

\subsection{LITERATURE STUDY}

According to Evans and Kowanko (2000), literature studies summarize past efforts in the research field. Andersen and Kragh (2010) claim that research is the tool for theory building, and the researcher is the instrument of observation and interpretation. Theoretical pre-understanding is important in theory building. Campbell (1975) and Eisenhardt (1989) raise the need for theory-building research through case study research by matching the theoretical pre-understanding with the observed outcome.

An in-depth study of the literature on remanufacturing, remanufacturing challenges and lean remanufacturing during a literature study satisfies the need for theoretical preunderstanding. Originating from the literature study on remanufacturing challenges and possible lean improvements, the research areas critical to the RQs were selected for further in-depth investigation at the case companies.

The search word and phrases used for the literature study were 'remanufacturing', 'remanufacturing challenges', and 'lean remanufacturing'. The sources for the literature review were academic publications in search and metasearch engines, including Science Direct, Scopus, Web of Knowledge, Journal of Remanufacturing and Google Scholar.

\subsection{INTERACTIVE RESEARCH}

The reason for selecting interactive research is its capacity to transform an understanding of remanufacturing issues from literature study to case study at four companies, consequently reducing the knowledge gap between theory and practice (see Aagard- 
Nielsen and Svensson, 2006). An interaction with four companies, performed during the Field phase of this thesis (see Figure 2), satisfied the data collection purpose and facilitated collaboration and sharing of the research results with the companies.

The Field phase includes active researcher participation in the companies' context for a short period, "being there and interacting with the organization" (Ellström et al., 1999; Bryman, 1989; Shadish et al., 2002; Acar Sesen and Mutlu, 2014), and systematically analyzing the research field by developing different applications for a studied phenomenon (Kuzu, 2009). Interactive research provided the basis for perceiving the research questions from the companies' perspective. This is another reason for selecting the interactive form of research.

\subsubsection{CASE STUDY APPROACH}

Eisenhardt (1989), Yin (1994), and Law (2004) emphasize the suitability of a case study approach for investigating complex research questions in a real-world context. The complexity of the thesis RQs and a need to investigate remanufacturing issues in a real context were the motives for selecting the case study approach. According to Yin (1994), case studies can generate theory from the interpretation of observations made in natural settings. Kuper and Kuper (1985) conclude that more discoveries have arisen from intense observations than from statistics applied to large groups. In this thesis, the research questions what and how are answered through the case study approach.

In this thesis, the case study focuses on identifying remanufacturing process challenges that prolong process lead time and possible improvements using lean. These issues were studied at four companies by following standard case study procedures and applying the same data collection methods, which enabled a smooth cross case analysis. Comparability of results from the executed case study simplified generalization. However, the research object in this case study is not a remanufacturing company or a group of people, but rather a remanufacturing process. The in-depth study of this research object was strengthened by using multiple sources of evidence (information sources, such as employees in different positions, and and data collection methods, such as a questionnaire, observation, and a focus group interview, including the Value Stream Mapping (VSM) tool, presented later in Section 3.2.3).

\subsubsection{DATA COLLECTION METHODS}

Flyvbjerg (2006) stated that the choice of data collection method should clearly depend on the problem under study and its circumstances. In this thesis, the case study takes a flexible approach regarding data collection methods. The case study encompasses a questionnaire, observation and a focus group interview (Morgan, 1997), which leads to a greater understanding of the research questions and answers, as well as ensuring data validity and reliability. The way in which each data collection method was used is demonstrated in Figure 3, which shows the procedures during the Field phase (see Section 2.1), which can be further divided into two steps: Preparation and Execution. 


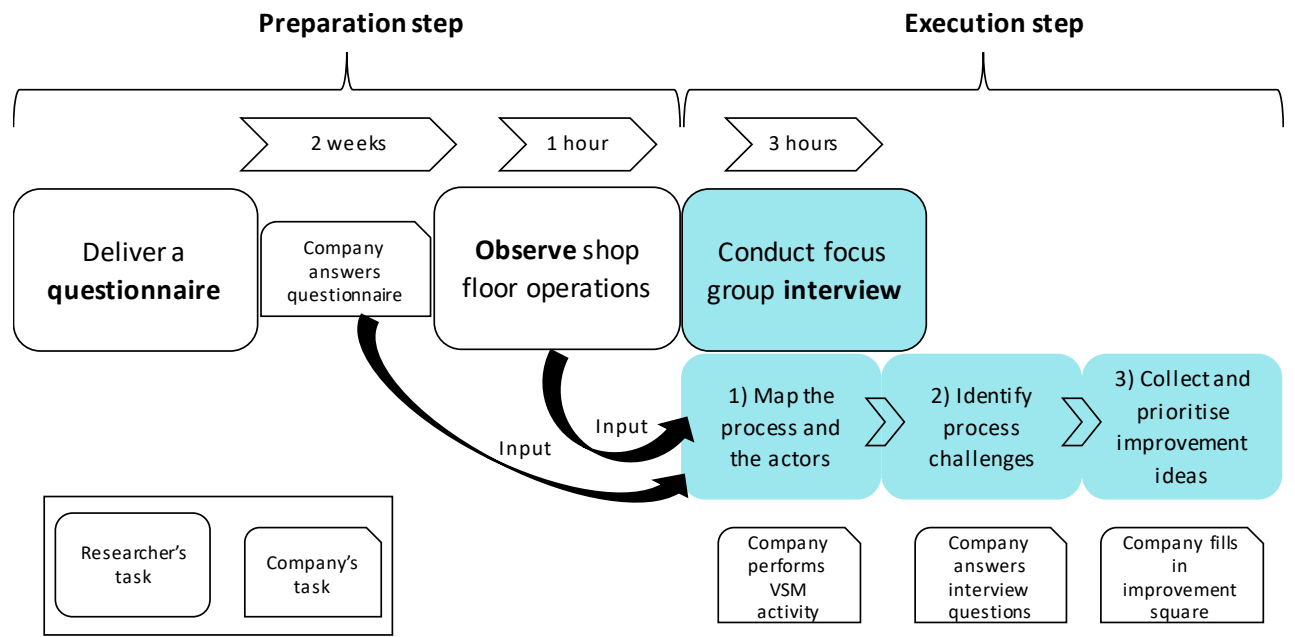

Figure 3: Field procedures during the case study.

\section{Preparation step}

A questionnaire was developed to collect statistical data on the remanufacturing process: lead time, product quality, inventory level and customer demand (see Appendix A). One questionnaire is devoted to each case company, aiming at managerial company representatives. In total, 15 questions were outlined in the form of bullet points requesting quantitative process data. This information was used during the focus group interview to develop a process map by the Value Stream Mapping (VSM) tool. A twoweek period was allocated for answering the questionnaire before the observation took place on the shop floor.

Observation provided rich qualitative data (Geertz, 1973) on the remanufacturers' processes and facilitated an understanding of each company's operational practices, material flow, information exchange, shop-floor layout, machinery, and other details. An observation of remanufacturing operations laid the foundations for the Execution step. The remanufacturing process observation was performed together with the factory manager and took between 30 minutes and one hour.

\section{Execution step}

A focus group interview was used to involve several company's representatives in a discussion on the research questions and elicit details of the remanufacturer's processes (see Appendix B). According to Morgan (1992) a focus group is a smaller group of participants (five to seven), selected to discuss interview questions of a highly sensitive and important nature to them. Bellenger et al. (2011) identified several uses of focus groups, varying from information collection and hypothesis generation for further testing, to idea generation about a new and creative process or product concept. In this 
thesis, focus group interviews provided detailed information about remanufacturing process, emphasizing the challenges that prolong lead time and suggesting possible solutions to those challenges.

There are several benefits to incorporating the focus group interview into case study research design. The first is its ability to deal with complex subjects and bring out information that might be missed by a statistical study (Lydecker, 1986). Another reason for choosing focus group interviews is their success in gathering in-depth information about many topics in a relatively short time. The flexibility of focus groups is another advantage, since participants improvise in potentially valuable topics of discussion (O'Donnell, 1988). A further benefit is that they are economic and a resource-efficient approach in terms of gathering data and providing/obtaining participant feedback (Barnett, 1989). Therefore, the collection of high-value data from focus group interviewing presents an opportunity for on-site data triangulation in this thesis. The focus group interviews with VSM lasted between two and three hours each and included five to seven company employees whose competences cover different functions, such as factory or process managers, planners, operators or technicians, administrators, sales, logistics, and quality managers. The sessions were recorded, transcribed and analyzed using qualitative content analysis (Kvale, 1996). The focus group interview session included three steps:

\section{1) Mapping the remanufacturing process and stakeholders}

A focus group interview combined with a VSM tool was used as the data collection method to identify remanufacturing process challenges that prolong process lead time and to develop possible improvements (Rother and Shook, 2003; for more details, see Paper II). This step invited participants to map all the important process operations and stakeholders on a large piece of paper. Process data, such as: the time for each operation, time for material transportation and holding at inventories, and number of employees, is entered in accordance with the VSM tool. During this step, the process lead time, time for operations and waiting time, as well as the process efficiency ratio, are calculated.

\section{2) Identify process challenges}

During the second step, the focus group participants discussed remanufacturing challenges, including those that contribute to the long process lead time, and marked them directly on the process map. The researcher steered the discussion by asking pre-defined questions. In total, more than 40 questions were covered during the second step (see Appendix B).

\section{3) Collect improvement ideas}

The third and final step involved collecting possible improvement ideas from participants in order to address the identified challenges. The main task in this step was to involve participants in developing solutions to the challenges. Finally, all 
the collected ideas were prioritized in an improvement square according to ease of implementation and the power to affect process lead time (see Appendix C). The collected challenges and improvement ideas became the basis for the selection of lean practices to address remanufacturing process challenges.

\subsection{VALIDITY, RELIABILITY AND GENERALIZABILITY}

According to Field (2013), internal validity refers to how credible one's findings are in comparison with reality. The question could be asked: Are we observing, identifying or measuring what we think we are studying? Here the issues of transparency are covered. Reliability reflects the phenomenon's repeatability, together with the consistency of results. The question to be answered here is: If the inquiry were replicated, would the findings be the same? External validity, or generalizability, in its turn covers the issue of research result generalization to a population from the case study (Field, 2013). However, going from a sample to a population is not the goal with case study research, but rather the intention is to generate in-depth knowledge about a phenomenon (Merriam, 1988). The following strategies were used in this thesis to approach research internal validity, reliability and external validity (generalizability) (see Table 2):

Table 2: The strategies used to ensure research validity, reliability and generalizability.

\begin{tabular}{|l|c|c|c|}
\hline Strategies & Validity & Reliability & Generalizability \\
\hline Triangulation & $\mathrm{X}$ & $\mathrm{X}$ & \\
\hline Member check & $\mathrm{X}$ & $\mathrm{X}$ & \\
\hline Peer examination & $\mathrm{X}$ & & \\
\hline Detailed description & & & $\mathrm{X}$ \\
\hline
\end{tabular}

- Triangulation entails the use of multiple observations, theoretical perspectives, sources of data and research methods to study the underlying phenomenon (Berg and Lunde, 2004). This thesis used both literature study and case study, while the case study approach employed multiple types of data collection methods and multiple levels of analysis to facilitate data triangulation, which, according to Yin (1994), originates from the need to validate research.

- Member check is another tactic recommended by Merriam (1988). It implies the assessment of findings by the participants in the data collection session. The research findings were assessed by the companies' employees who participated in the focus group interview on two occasions: the feedback session and the resultsharing session. 
- Peer examination is proposed by Guba and Lincoln (1994) as one of several criteria to assess the quality of research. They assume that the peer should act as an auditor to ensure that the research has been performed properly. Assessment by peer researchers and experts in remanufacturing and lean has been an important part of improving the quality of this thesis.

- Detailed description of the data collection procedures, analysis and research results is a recognized way to cover the issue of findings generalizability (Bryman, 2015). This thesis provides details of the collected data and a detailed explanation of the performed analysis that led to the research results.

As it is shown in Table 2, validity is ensured by triangulation, a member check and peer examination. The need for triangulation is satisfied through the multiple data collection methods (see Section 2.3) (Merriam, 1988; Eisenhardt, 1989). Another technique to ensure internal research validity is the member check, which ensures that the data collected at the industrial case companies has been properly interpreted. The findings from each case company were validated by the focus group participants. This is a key step in verification of the collected facts, results and conclusions. Additionally, a peer examination technique was utilized to strengthen the research findings by questioning senior colleagues and experts in the areas of lean and remanufacturing.

Reliability is covered through triangulation and the member check. Case study reliability is also based on research transparency, stability, data collection repeatability, and data analysis method accuracy (Merriam, 1988). A pilot case study ensured that the data collection and analysis methods were suitable to answer the two research questions. Welldocumented field procedures can be easily repeated by other researchers and practitioners. In this thesis, the VSM tool was used for visualization purposes to enable transparent discussion and on-site data triangulation.

A detailed description of the data collection method, analysis and research results is suitable for ensuring generalizability (Merriam, 1988). Details of the performed research can provide explicit information about the research area, which helps to determine other researchers' positions in respect to the research performed. However, as noted by Flyvbjerg (2006), "generalization of the findings is often overvalued as a source of scientific development, whereas 'the force of example' is underestimated." 


\section{THEORETICAL BACKGROUND}

This chapter describes the theoretical foundations of the research. First, the research areas of lean and remanufacturing are plotted, followed by a conjoined research area of lean remanufacturing. Thus, this chapter defines the starting point of the research and provides the researcher's perception of related research areas.

\subsection{MAPPING THE RESEARCH AREA}

Lean has its roots in manufacturing research. In particular, lean's contribution to automotive manufacturers' productivity and efficiency improvements became an attractive research field. Lean is now spreading to other areas than the original manufacturing: into processing industries, and further to service ones, leading to numerous modifications and combinations of lean application (Modig and Åhlström, 2012). However, each industry adjusts the application of lean according to its specific characteristics (Modig and Åhlström, 2012).

Remanufacturing in its turn belongs to the family of research subjects that has a great interest in sustainable development, with the $\mathrm{CE}$ as a regenerative system at the forefront. Lean remanufacturing is a newly formed research area to be studied in this thesis. The following text takes a deeper look at the research areas of lean, remanufacturing and the conjoined area of lean remanufacturing.

\subsection{LEAN}

Lean has emerged from the Toyota Production System (TPS) into a common improvement strategy to address companies' challenges (Womack and Jones, 2003; 
Joseph, 2006). According to Pettersen (2009), lean is ruled by a philosophy of continuous improvement towards the elimination of any unnecessary operations and the creation of value for customers. The term value in lean comes together with the lean initiative of doing more with less time, less human effort, less machinery, and less material, and at the same time delivering the products that customers demand (Pascal, 2002; Bicheno, 2004).

\subsubsection{LEAN PRINCIPLES}

Womack and Jones (2003) explain the concept through specifying 5 lean principles: value, value streaming, continuous flow, a pull or pulled ordering system, and pursued perfection.

Value designates what the customer is asking for or, according to Ohno (1988), value is processing that the customer is eager to pay for. Lean enfolds value by separating valueadded operations from non-value-added ones, which are treated as waste to be eliminated (see more in Section 3.1.2). Therefore, value generation is a pure aim of lean.

Value streaming denotes directing operations towards value generation. When streaming the value, every production process operation, every task, material and information flow, is inspected to define its contribution to value generation. Therefore, value streaming lays the foundation for the identification of non-value-added operations. Womack and Jones (2007) stress value streaming as an alternative to looking at comprehensive processes performed by isolated machines.

Flow links the value-added operations in an efficient chain or critical product path (Parry and Turner, 2006). Flow is a key attribute of stream thinking. Creating continuous process flow is essential to reduce/eliminate process waste. To achieve continuous flow, lean companies employ a system of triggers and control mechanisms that, for example, eliminate unnecessary material transportation and storage between sequential process steps (Ohno, 1988). Material and information flows are two key flows in lean (Jones and Womack, 2003).

Pull synchronizes production pace with real customer demand. Actual demand is linked to production pace. Pull is enabled by a trigger that signals the need to initiate operations in the upstream process. Liker (2004) explains pull as a system to refill what has been taken by the process upstream to fulfill customer demand. In this way, the downstream process pulls products from upstream, creating a linked product chain - flow.

Perfection is the goal of lean and consists of striving for the best quality, lowest costs, shortest lead times, greatest safety and highest morale (Ahlstrom, 1997).

\subsubsection{WASTE, VARIABILITY AND INFLEXIBILITY ACCORDING TO LEAN}

In lean, all challenges can be attributed to some form of waste, variability or inflexibility (McKinsey and Company, 2014) (see Table 3). 
Table 3: Forms of waste, variability and inflexibility according to lean (adapted from McKinsey and Company, 2014).

\begin{tabular}{|l|l|l|}
\hline Waste & Variability & Inflexibility \\
\hline 1. Waiting & 1. Material & 1. Mix \\
2. Inventory & 2. Information & 2. Product \\
3. Motion & 3. People & 3. Volume \\
4. Over-processing & 4. Process & 4. Delivery \\
5. Transport & 5. Environment & \\
6. Over-production & & \\
7. Defects, rework and scrap & & \\
\hline
\end{tabular}

Waste is everything that does not add value and, according to Pascal (2002), waste elimination is one of the most effective ways to increase profitability. According to McKinsey and Company (2014), waste in processes typically signifies the use of resources beyond what is needed to meet customer requirements. The seven wastes concept was developed by Ohno (1988) for the TPS. These seven most typical wastes are: motion, waiting, conveyance/transporting, correction/rework, over-processing, overproduction, and inventory. The most dangerous source of waste is inventory, especially work-in-progress inventory (WIP), since it conceals problems (Ohno, 1988; Ahlstrom, 1997).

Variability refers to process instability due to deviations from standard materials, information, people, processes, and environment (McKinsey and Company, 2014).

Inflexibility is an inability to effectively respond to changes in the current system, resulting in additional costs incurred by not giving customers exactly what they want: product or product mix, volume, or delivery (McKinsey and Company, 2014).

\subsubsection{LEAN TOOLS AND PRACTICES}

Lean follows a holistic approach to reduce or eliminate waste, variability and inflexibility which cause a number of challenges that reduce process performance (McKinsey and Company, 2014). When discussing lean operational capability to improve process performance, several lean tools and practices could be applied. Lean tools and practices and their effects in different areas are listed in Table 4. 
Table 4: Most common lean tools and practices (adapted from Bicheno and Holweg, 2009) for improvements at operational level (adapted from Shah and Ward, 2007).

\begin{tabular}{|c|c|}
\hline $\begin{array}{l}\text { Improvements in } \\
\text { common terms }\end{array}$ & Appropriate lean tools and practices \\
\hline $\begin{array}{l}\text { Product delivery: } \\
\text { internal and external } \\
\text { from suppliers and to } \\
\text { customer }\end{array}$ & $\begin{array}{l}\text { Just-in-time (JIT); Kanban; Supplier partnerships (quality levels); } \\
\text { Quality function deployment (QFD) for customer involvement }\end{array}$ \\
\hline Quality management & $\begin{array}{l}\text { Standard Operating Procedures; Jidoka (prevention, detection and } \\
\text { elimination of errors and mistakes); Total Quality Management (TQM); } \\
\text { TPM (Total Productive Maintenance); 5S (sort, set in order, shine, } \\
\text { standardize, and sustain); Visual Management; Mistake-proofing } \\
\text { (Pokayoke); Value Stream Mapping (VSM); Spaghetti diagram }\end{array}$ \\
\hline Setup time reduction & Single minute exchange of dies (SMED); Kitting \\
\hline Process and layout & Product families; layout for continuous flow; cellular layout \\
\hline $\begin{array}{l}\text { Operations planning } \\
\text { and scheduling }\end{array}$ & $\begin{array}{l}\text { Heijunka (Level out schedule); Small batch size; Supermarkets; FIFO } \\
\text { (first in first out) lanes; Demand smoothing; Takt time; Eleven } \\
\text { scheduling concepts }\end{array}$ \\
\hline $\begin{array}{l}\text { Continuous } \\
\text { improvement }\end{array}$ & $\begin{array}{l}\text { Kaizen events; } 5 \text { Whys; PDCA (Plan, Do, Check, Act); DMAIC (Define, } \\
\text { Measure, Analyze, Improve, Control) }\end{array}$ \\
\hline $\begin{array}{l}\text { Statistical process } \\
\text { control }\end{array}$ & Six Sigma; OEE (Overall equipment efficiency) \\
\hline $\begin{array}{l}\text { Employee commitment } \\
\text { and management }\end{array}$ & $\begin{array}{l}\text { Cross functional teams; Policy deployment matrix; Concern, Cause, } \\
\text { Countermeasure (3C); Group problem solving; Skill matrix; Training } \\
\text { within Industry (TWI); Supervision and Mentorship; Lean culture }\end{array}$ \\
\hline Product design & $\begin{array}{l}\text { Design for X (modularity, platforms, components); LAMDA (Look, } \\
\text { Ask, Model, Discuss and Act) }\end{array}$ \\
\hline
\end{tabular}

Six lean practices and a VSM tool, used for data collection and analysis in this thesis, are described below due to their greater impact on manufacturing lead time reduction (see Shah and Ward, 2007; Bicheno and Holweg, 2009; Modig and Åhlström, 2012).

\section{- Value Stream Mapping}

The VSM tool is often used as a mapping tool in lean to develop an overview of production operations, including material and information flow as well as connections to external stakeholders (Rother and Shook, 2003). In VSM, the main company's operations are schematically mapped in their actual sequence to reflect the production process 
operations, inventory, and other process-relevant information. With the help of VSM, companies can identify challenges and develop possible improvements (Jones and Womack, 2003). VSM is a recognized stream thinking tool that helps to distinguish valueadded from non-value-added operations and determine waiting time (Jones and Womack, 2003). In this thesis, the VSM tool was additionally used for visualization purposes during the data collection stage. Visual data representation enables transparent discussion and on-site data triangulation and enables analysis of the data.

\section{- Product families}

According to Groover (2008), product family entitles a group of products with similar design (geometric shape and size) and/or manufacturing characteristics (tolerances, production quantities, and material) possessing similar processing or assembly operations. Product separation into families is an effective mechanism for controlling process capacity, routing products through the factory and establishing a more defined process lead time (Bicheno and Holweg, 2009). In lean, a product family reflects a product and its variants that are passing through similar processing steps and utilizing common equipment. Arranging the production process according to the distinct product families facilitates the overall process efficiency (Groover, 2008).

\section{- Kanban}

Kanban is a material ordering system that can be used as a main production control tool (Morgan and Liker, 2006). Kanban refers to a system of triggering mechanisms that synchronizes process pace with real consumer demand. By pulling products from the upstream process, the downstream process sends a signal for the replenishment of the collected parts to the previous process (Liker, 2004). In this way, kanban creates a link between downstream and upstream processes.

The word kanban in Japanese means signboard or billboard, which refers to a visual tool (Dennis, 2002). According to Dennis (2002), the kanban system is typically applied using cards which display information about: supplier of the part, storage area and transport routines. But the request for part replenishment could be signaled through the empty space on the shelf or empty box for the spare part. Through the application of a kanban system, only what has been removed from storage will be produced and replenished, and in this way no unnecessary production will take place (Dennis, 2002; Morgan and Liker, 2006).

Kanban is a central part of lean for achieving process stability (Bergman and Klefsjö, 2012). Therefore, employing a kanban ordering system is a plausible means of controlling the process lead time. Additionally, kanban helps to avoid the need for large storage areas by keeping only the required raw materials and spare parts before the defined processes.

- Layout for continuous flow

An appropriate design for the facility layout contributes to creating continuous process flow (Bouzon et al., 2012; The Productivity Development Team, 1999). This implies 
linking separate remanufacturing operations into a smooth, undisrupted process chain while removing any interruption between them. One possibility for improving layout is to perform remanufacturing process operations in cells. A cellular layout is achieved through process organization into cells, shaped in arches like a " $U$ " or a "C" that arrange equipment in sequential order. A cellular layout with small batches ensures quicker control over the arriving products, providing rapid feedback to the previous process. By introducing a cellular layout, companies improve the communication between employees working in each cell (McLaughlin and Durazo-Cardenas, 2013), avoiding walking and unnecessary product transport between operations. Additionally, the layout for continuous flow attempts to optimize inventory levels and reduce lead time, especially in processing information, and therefore benefits with improved process efficiency (Sugimori et al., 1977).

\section{- Cross functional teams}

Cross functional teams involve grouping employees into dedicated product teams that are responsible for a product from raw material acquisition to shipment to the customer. This is an efficient practice to deal with complex shop-floor operations and improve information sharing among employees (Bicheno and Holweg, 2009). Improved employee cross-training and learning through problem solving is another benefit associated with the introduction of the cross functional team. Group problem solving is a dynamic, hands-on learning activity that involves knowledge sharing and teaching essential skills by the area expert or leader (Bicheno and Holweg, 2009).

\section{- Standard Operating Procedures}

Standard operating procedures lay a stable foundation for building further improvements to companies' challenges (Bicheno and Holweg, 2009). Based on the best practice of employees, standard operations are designed, tested, improved and applied to manufacturing processes. Therefore, the standard procedures (instructions and checklists) are not static but undergo continuous revisions and improvements to match the best practice of employees. Developed by the employees, who are directly involved in performing the tasks, standard operating procedures reduce deviations in process operations.

Instructions, one tool of standard operating procedures, contain images and brief text descriptions to facilitate a better understanding by employees. Another tool is a checklist that encompasses a list of items or tasks to be performed in the recommended order. Checklists can be applied together with the instructions to achieve the best performance.

The most valuable advantages of standard operating procedures are reductions in process lead time due to a reduction in waiting time for required materials and information as well as reductions in process errors and reworks (Gnanavel et al., 2015; Carlo et al., 2013). 


\section{- Supplier partnerships}

Lean has established practices that companies can utilize to successfully bring together the necessary cooperation elements to form reliable and trustworthy partnerships (for details, see Liker and Choi, 2004). Liker and Choi (2004) have identified the six best partnering practices with a positive effect on cooperation with suppliers and customers:

- share information intensively, but selectively

- conduct joint improvement activities

- develop suppliers' and customers' technical capabilities

- supervise suppliers/customers

- turn supplier rivalry into opportunity

- understand how suppliers and customers work

According to Liker and Choi (2004), in order to boost the cooperative elements and enable data sharing between stakeholders, each of these six aspects has to be implemented.

\subsubsection{PROCESS LEAD TIME}

Within lean, time is the most important factor, since the efficiency of a process is measured based on process lead time (Duggan, 2002). Ohno (1988), a father of TPS, also emphasizes the process lead time. He claims that: "All we are doing is looking at the time line, from the moment the customer gives us an order to the point when we collect the cash. And we are reducing the time line by reducing the non-value adding wastes". Therefore, one possible way to identify process challenges is to study process lead time, which is one key lean performance indicator (Bicheno and Holweg, 2009).

Process lead time can be separated into the time for operations used to perform both valueadded and non-valued-added operations and the waiting time (see Figure 4). According to Duggan (2002), to measure process lead time all the times for process operations added up to each other, plus all the waiting times between the process operations.

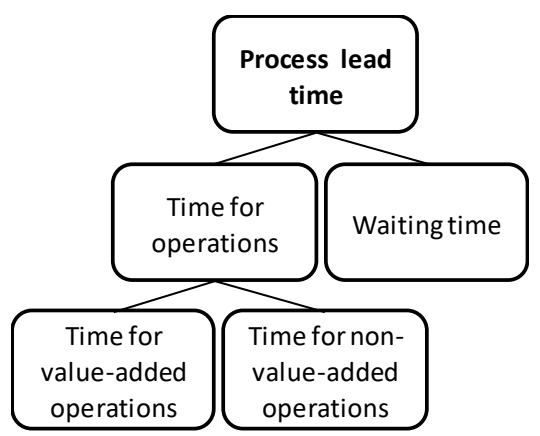

Figure 4: Process lead time (adapted from Bicheno and Holweg, 2009). 
Process lead time is calculated as:

$$
\text { Process lead time }=\text { Time for operations }+ \text { Waiting time }
$$

Time for operations:

Time for operations $=$ Time for value added operations + time for non value added operations

Value-added operations are the type of operations that a manufacturer is willing to keep, since they generate value to the customer. Non-value-added operations can be further divided into unnecessary, which have to be eliminated (for example: non-ergonomic employee movement, relocation of materials, observing the equipment or machines working, and walking to get a tool), and unavoidable, which cannot be eliminated but need to be minimized (for example: some kinds of internal transportation, some activities used during changeover operations) (Jones and Womack, 2003). However, all operations, even the value-added ones, could be improved: simplified, combined or performed in parallel.

Waiting time is the time before, between or directly after remanufacturing operations; it includes the time spent waiting for raw material or spare part delivery or storage of raw materials, work in progress or finished goods inventories. Waiting time does not add any value and has to be eliminated or reduced (Bicheno and Holweg, 2009).

Process efficiency is dependent on how the process lead time is shared between time for operations and waiting time. Furthermore, the higher the proportion of time used for value-added operations in process lead time, the higher the process efficiency. The time for value-added operations is divided by the process lead time to calculate the efficiency value (Bicheno and Holweg, 2009).

$$
\text { Process efficiency }=\frac{\text { Time for value added operations }}{\text { Process lead time }}
$$

$$
\text { Process efficiency }=\frac{\text { Time for value added operations }}{\text { Time for value added }+ \text { non value added operations }+ \text { Waiting time }}
$$

\subsection{REMANUFACTURING}

Remanufacturing is an important part of a CE, which brings previously used products and their parts back into useful life (APSRG, 2014). This industrialized process denotes a series of steps applied to a core in order to return it to like-new or better performance (Steinhilper, 1998; Östlin et al., 2008). Through remanufacturing, products, their parts and embodied material remain in use for longer, implying a substantial reduction in the 
use of energy and water as well as the emissions to air required for new product manufacturing (CRR, 2007).

The remanufacturing industry stretches from heavy machinery and aircraft to automotive parts and healthcare tools, and even into the IT and furniture sectors. The three most common categories of relationships between remanufacturers and Original Equipment Manufacturers (OEMs) are (see, e.g. Lund, 1983):

- Original Equipment Remanufacturers (OERs) - Companies that remanufacture their own products.

- Contracted Remanufacturers (CRs) - Companies that are contracted to remanufacture products on behalf of other companies, typically OEM.

- Independent Remanufacturers (IRs) - Companies that remanufacture products with little or no contact with the OEM, and that need to buy or collect cores for their process.

OEMs that remanufacture have control over product development and product recovery processes, while a contracted remanufacturer has limited access to the OEM's expertise, and an independent remanufacturer can be an OEM competitor.

As estimated in the report by European Remanufacturing Network (ERN) (Parker et al., 2015) in Europe alone, the remanufacturing industry generates billions of euros every year and creates new skilled jobs. Despite remanufacturing growth into different sectors, these companies face challenges (APSRG, 2014). The most common challenges are: lack of technology appropriate for remanufacturing operations; lack of product knowledge due to limited access to OEMs' product specifications and manuals; lack of sales channels and discrepancies with new product sales; some legislation restrictions; high labor costs due to the large proportion of manual work; insufficient quality of the products returned for remanufacturing; insufficient volume or availability of cores; and, finally, low customer recognition of the remanufactured products (Parker et al., 2015).

\subsubsection{REMANUFACTURING PROCESS}

During the remanufacturing process, the core passes through a number of remanufacturing operations, e.g.: Inspection, Cleaning, Disassembly, Reprocessing, Reassembly, and Testing to ensure that it meets the desired product performance (Steinhilper, 1998; Sundin and Bras, 2005) (see Figure 5).

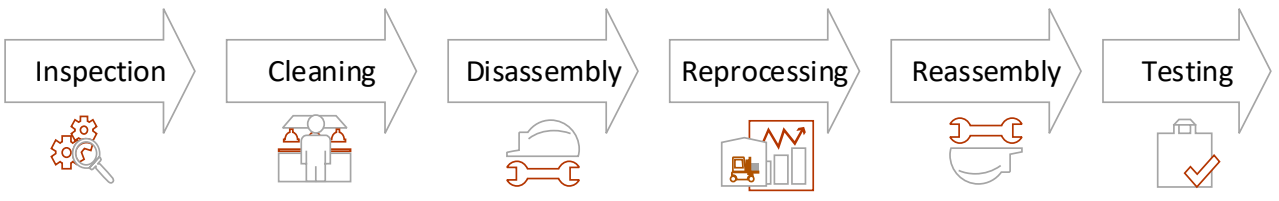

Figure 5: Remanufacturing process operations (based on Guide, 2000; Seitz and Peattie, 2004; Sundin, 2006). 
One important aspect when comparing remanufacturing to manufacturing is Inspectionthe quality control of incoming material, when the quality is much lower at remanufacturing facilities. Cores vary in condition due to different consumption purposes and use patterns. As a result, remanufacturing tends to have a higher level of uncertainty in process steps and time, as well as unpredictability in core quality and quantity, when compared to manufacturing (Steinhilper, 1998; Guide, 2000; Seitz and Peattie, 2004; Van Nunen and Zuidwijk, 2004; Sundin, 2006; Lundmark et al., 2009).

Remanufacturing process lead time is typically longer and more variable than in manufacturing (Guide, 2000; Seitz and Peattie, 2004; Sundin, 2006). Due to the unpredictable and uneven nature of core return, remanufacturers tend to store vast amounts of inventory for a long time. (Seitz and Peattie, 2004). This inventory occupies a lot of space and can cause operating complexity inside the facility.

Guide (2000) has summarized some characteristics of remanufacturing process:

- Uncertain timing and quantity of returns

- Uncertainty in material recovery

- Need to balance return of used products with demand for remanufactured products

- Problems of stochastic routings for materials and variable processing time

- Need for disassembly of returns

- Requirement for a reverse logistics network

- Material restrictions

\subsection{LEAN REMANUFACTURING}

Lean Remanufacturing emerged not long after the remanufacturing research area itself. The earlier lean remanufacturing research was questioned due to the absence of stable demand and supply in remanufacturing, which are the prerequisites to work with lean according to some researchers (Seitz and Peattie, 2004). They claim that establishing the types of lean and mass customization systems that manufacturers depend on is practically impossible.

Furthermore, the remanufacturing process presents many specific process challenges compared to a manufacturing process (Lund, 1983). For example, traditional manufacturing process is often highly repetitive, and variability is typically a result of internal processing (Kucher, 2008). In remanufacturing variability is an essential part of the process due to the characteristics of remanufacturing, related to core condition (Kucher, 2008). According to this researcher, remanufactured product can be compared to an engineered-to-order product with different specifications and unique process operations. He claims that the variation in incoming core quality complicates the application of lean manufacturing tools and practices to remanufacturing context. This finding supports the observation made by Östlin and Ekholm (2007) in their study on 
toner cartridge remanufacturing company. Pawlik et al. (2013a) identified that the uncertainty involved in incoming cores, in particularly core quality, might be the key problem in the application of the lean manufacturing tools within an automotive remanufacturing shop floor.

Nevertheless, in his findings, Kucher (2008) identified the possibility of adjusting the application of lean tools depending on the levels of product variety and volume in remanufacturing. Kucher (2008) defined seven types of waste in remanufacturing (see Table 5).

Table 5: Common examples of waste in remanufacturing (Kucher, 2008).

\begin{tabular}{|c|c|}
\hline & Common Examples of Waste in Remanufacturing \\
\hline Overproduction & $\begin{array}{l}\text { - } \quad \text { Processing materials and components before the required time. } \\
\text { - } \quad \text { Processing components that ultimately can not be remanufactured. } \\
\text { - } \quad \text { Remanufactured components becoming obsolete. }\end{array}$ \\
\hline Waiting & $\begin{array}{l}\text { - Last-out first-in disassembly to re-assembly cycle leaves components idle. } \\
\text { - Difficulty in aligning all resources (production, logistics, engineering, lifting } \\
\text { \& handling, other support) at the work site. }\end{array}$ \\
\hline $\begin{array}{l}\text { Unnecessary } \\
\text { Transport }\end{array}$ & $\begin{array}{l}\text { - Geometric complexities of disassembling large and complex systems with } \\
\text { components being worked in smaller machine shop environments. } \\
\text { - } \quad \text { Large industrial footprint of most remanufacturing organizations }\end{array}$ \\
\hline Overprocessing & $\begin{array}{l}\text { - Tendency to error on the side of conservatism is hand-processed } \\
\text { remanufactured materials and components. } \\
\text { - Complex and interrelated customer/supplier relationships. }\end{array}$ \\
\hline Excess Inventory & $\begin{array}{l}\text { - A "bow wave" of materials and components is created as products are torn } \\
\text { apart very quickly, only to be repaired and re-assembled more slowly. } \\
\text { - Supply system must support a variety of condition/processing contingencies. }\end{array}$ \\
\hline $\begin{array}{l}\text { Unnecessary } \\
\text { Movement }\end{array}$ & $\begin{array}{l}\text { - Large industrial footprint of most remanufacturing organizations. } \\
\text { - Difficulty in aligning all resources (production, logistics, engineering, lifting } \\
\text { \& handling, other support) at the work site. }\end{array}$ \\
\hline Defects & $\begin{array}{l}\text { - Overly-aggressive, overly-optimistic, or overly creative strategy for materials } \\
\text { and components; resulting in: incorrect assessment of condition or } \\
\text { incorrect processing of component. }\end{array}$ \\
\hline $\begin{array}{l}\text { Unused Employee } \\
\text { Creativity }\end{array}$ & $\begin{array}{l}\text { Many remanufacturing tasks are non-repetitive and more difficult to } \\
\text { incorporate employee ideas into future processing. }\end{array}$ \\
\hline
\end{tabular}

Pawlik et al. (2013b) stated that the combination of remanufacturing with lean principles appears to offer a plausible methodology for increasing process efficiency. Today, remanufacturing researchers treat lean as a set of principles and tools to gain operational efficiency and increase productivity in remanufacturing by keeping the original lean principles and adjusting lean tools and practices to match remanufacturing characteristics (Jacobs and Chase, 2001; Fargher, 2006; Sundin, 2006; Östlin and Ekholm, 2007; Kucher, 2008; Pawlik et al., 2013b). 
The potential and positive effect of applying lean to remanufacturing has also been noted by Fargher (2006), Sundin (2006), and Östlin and Ekholm (2007). Guide (2000) proposed the drum-buffer-rope planning system, which can be compared to the pull system actively used by lean manufacturers. He considered a customer pull to be a signal to start remanufacturing operations. Hunter and Black (2007) provided another example of the successful implementation of lean tools in improving remanufacturing process flow within a cellular layout. Like Hunter and Black (2007), Bouzon et al. (2012) have proposed a cellular layout to increase remanufacturing efficiency (see Figure 6). These researchers emphasize several issues to consider before the establishment of a cellular layout in remanufacturing: the variability of core supply, variability of work content due to variation in the core quality, and the difficulty in balancing the supply with the demand.

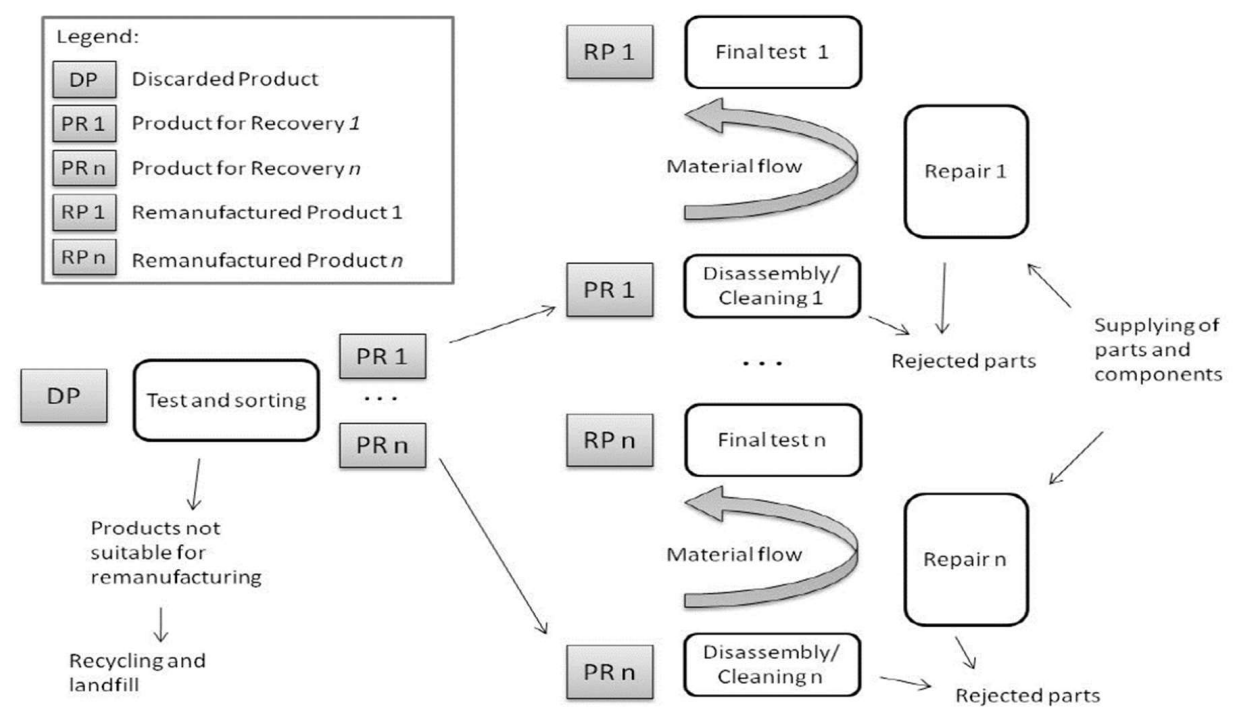

Figure 6: Cellular layout at remanufacturing facility (Bouzon et. al., 2012).

Kanikula and Koch (2011) developed nine kanban replenishment scenarios, including: inventory management, pull system, First In First Out (FIFO) lanes and supermarket controlled buffer, in remanufacturing. Each of the proposed scenarios is based on the different remanufacturing conditions: instable disassemble or repair cycle time; unstable recovery percentage at disassemble or repair; lack of space to store the core; recommended inventory for disassembled parts, repaired parts, and finished goods; no need to control disassembly process; disassemble or repair is expensive and time consuming; high cost of finished products inventory; and different cycle time in each process. 


\section{Process LEAD TIME CHALLENGES WITHIN}

\section{REMANUFACTURING}

This chapter describes the identified remanufacturing process challenges that contribute to long process lead time, based on results from the literature and case studies. This chapter gives a detailed description of the remanufacturing process operations at four remanufacturing companies, their process lead times and challenges associated with long process lead time.

\subsection{REMANUFACTURING PROCESSES AT THE CASE COMPANIES}

\subsubsection{CASE COMPANIES}

Four remanufacturing companies' processes were studied through a case study approach (see Section 2.3.1). The selected companies represent different business areas and products, ensuring a broad range of remanufacturing process challenges (see Table 6). 
Table 6: Overview of companies' characteristics.

\begin{tabular}{|l|c|c|c|c|}
\hline Characteristics & Company A & Company B & Company C & Company D \\
\hline Company size & Large & Large & Small & Large \\
\hline Industry sector & Machines & Automotive & IT equipment & Machines \\
\hline $\begin{array}{l}\text { Products } \\
\text { Remanufacturing category }\end{array}$ & Forklift trucks & Car engines & Laptops & $\begin{array}{c}\text { Filling } \\
\text { machines }\end{array}$ \\
\hline $\begin{array}{l}\text { Remanufacturing } \\
\text { experience }\end{array}$ & $>10$ years & $>20$ years & $>10$ years & $>10$ years \\
\hline $\begin{array}{l}\text { Product complexity } \\
\text { (number of components } \\
\text { aimed for } \\
\text { remanufacturing) }\end{array}$ & High & Medium & Low & High \\
\hline $\begin{array}{l}\text { Product price } \\
\text { Remanufacturing strategy }\end{array}$ & Make-to-stock & Make-to-order & Make-to-stock & Make-to-order \\
\hline
\end{tabular}

The case companies' process operations and their lead times were also studied and are visualized in figure 8-11. This thesis defines remanufacturing process lead time as:

"the time from core arrival from supplier to the remanufactured product shipment to the customer".

The studied time factor is based on the average time for operations and waiting attained from the Questionnaires (see Appendix A) estimated for one critical to each company remanufactured product. In order to describe the remanufacturing process and the lead time distribution at the companies studied, several symbols are used (see Figure 7). 


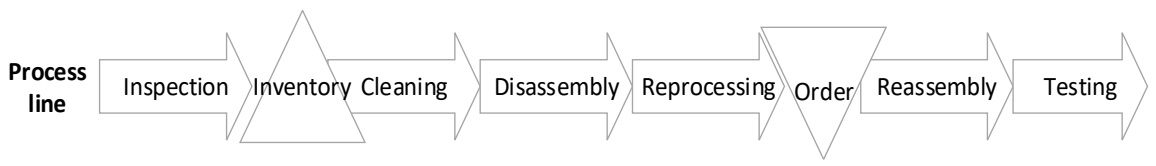

Lead time line days

\section{Process line symbols:}

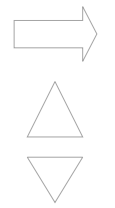

Remanufacturing process operation

Waiting at inventory (core, work-in-progress (WIP), and finished goods inventory)

Waiting for order (core or spare part: information or material)

\section{Lead time line symbols:}

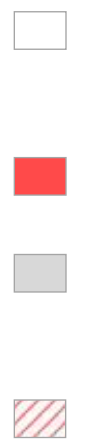

Time for operations is a portion of process lead time minus waiting time. Time for operations incorporates time used to perform both value-added and non-valued-added operations (see also Section 3.2.4).

Waiting time is the time spent on waiting for the raw material or spare part delivery or holding WIP or finished goods inventories (see also Section 3.2.4).

Unavoidable waiting time - waiting time at core inventory. This type of waiting is classified as unavoidable, since it is difficult to prevent due to remanufacturers having little or no control over core delivery. This time is not used for calculating process efficiency.

Partly waiting time is used when it is not easy to separate time for operations from waiting time and more data is needed.

Figure 7: Remanufacturing process and lead time symbols used in this thesis.

\subsubsection{REMANUFACTURING PROCESS AT COMPANY A}

Company A (Pilot) belongs to an original forklift truck manufacturer and provides remanufacturing services for OEM's used forklift trucks. Most cores come from forklift trucks that have been on rental agreement for 5-6 years. However, within this thesis the remanufacturing process of used forklifts without a rental agreement is studies. This process tends to have a longer lead time than the ones on rental agreement. The returned cores arrive at the remanufacturer, where they undergo six process operations and waiting (see Figure 8). 

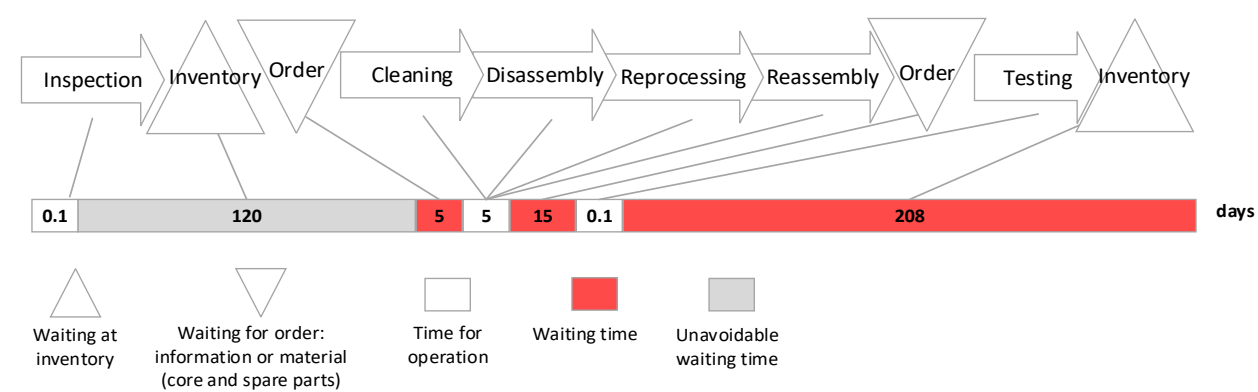

Figure 8: Process operations and process lead time at Company A.

During the Inspection process operation, cores are visually inspected and documented. Their condition is checked, the operating time is examined, and a test run is performed in order to classify cores on a scale of 1-3, with 1 being best and 3 least good. A photo of the core is taken and placed on the company's webpage.

Core Inventory is often a long-term placement for every used forklift truck received. Typically, the forklifts on rental agreement go directly to the Cleaning process operation, since they have a customer willing to use them in a short while. If the customer places an order for a remanufactured forklift truck, priority is given to the trucks waiting in the finished goods Inventory. If the customer cannot find an acceptable product, the remanufacturing process is initiated, and the core is transported to the Cleaning process operation. However, information on incoming customer orders is typically delayed or appears to be incomplete, which hinders the beginning of the Cleaning operation.

During the Cleaning operation, forklift trucks are washed in a separate room to remove any oil, dirt, rust and old paints. Then cores are moved to the work station for the following operations.

During the Disassembly, Reprocessing, and Reassembly process operations, one work station is typically occupied by two forklifts due to the three-to-four-week waiting time for spare part delivery. This waiting time is due to unexpected part malfunctioning discovered during the Disassembly or Reprocessing process operations.

After the remanufacturing operations have been accomplished, the final step is Testing or quality inspection, usually performed by the facility manager or planner. Since the company operates according to the Make-to-stock strategy, the remanufacturing process is often initiated without a customer order. Consequently, a large number of remanufactured forklifts appear in the finished goods inventory. On average, there are around 100 remanufactured forklift trucks of the most popular types in the finished goods inventory. 
Typically, these remanufactured forklifts are sold through another rental contract or on the second-hand market under the standard known as approved used forklift, with a guarantee of three to nine months (a more comprehensive description of Company A's process can be found in appended Paper II).

\subsubsection{Remanufacturing PROCESS AT COMPANy B}

Company $B$ is a contracted car engine remanufacturer with a monthly demand for remanufactured engines from the OEM, which remains a supplier of spare parts. An agreed monthly demand is 40 remanufactured engines. The remanufacturing contract implies no investment in core acquisition. When the returned core arrives at the warehouse, the remanufacturing process is initiated. A typical engine remanufacturing process is shown in Figure 9.

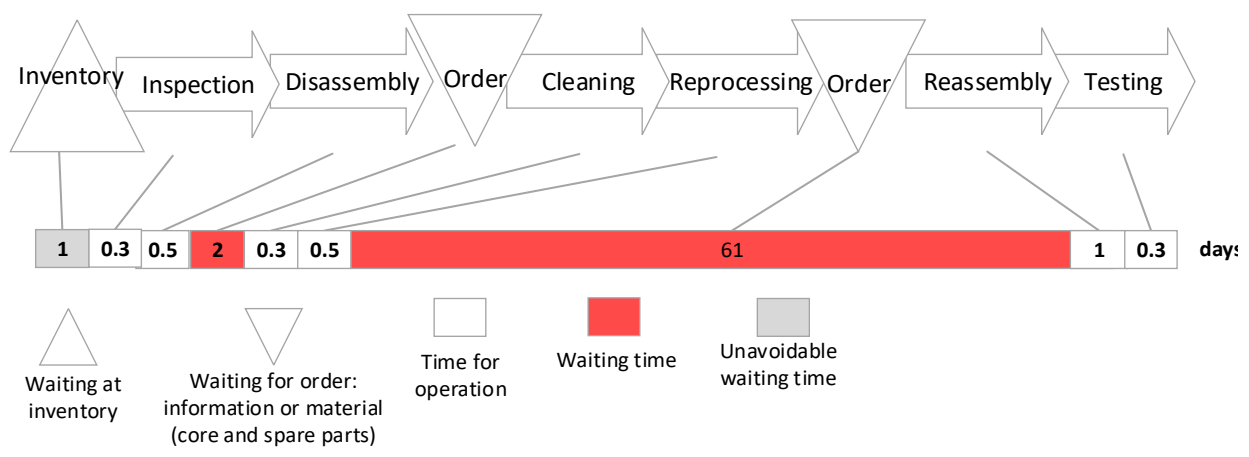

Figure 9: Process operations and process lead time at Company B.

The delivered cores are stored in a core Inventory in a neighboring warehouse for one day before they are moved to the remanufacturing facility for Inspection.

The Inspection step is devoted to controlling the quality of the returned engines, visual inspection being the main method. During this process operation, the core quality is checked, a photo is taken, and the damage is documented.

Later, the core goes to Disassembly, where it is disassembled into four master parts. Each of the parts follows its own process flow through Cleaning and Reprocessing until all the parts meet again for the Reassembly operation. The typical engine remanufacturing process implies ordering spare parts to replace broken ones; sometimes the waiting time for special spare part delivery stops the whole process for several months, which is shown in Figure 9 in red.

When the Reassembly process is finished, the engines go through the Testing operation and are sent to the OEM in batches of eight (a more comprehensive description of Company B's process can be found in appended Paper III). 


\subsubsection{REMANUFACTURING PROCESS AT COMPANY C}

Company $C$ is an independent IT remanufacturer of desktop computers, laptops and smartphones. The key duties are to manage the inflow of cores, classify their quality, and erase their data. Typically, avoiding Disassembly and the following remanufacturing process operations, products that are approved for the highest quality category are sold to local end users, while products of lesser quality are sold to resellers and remanufacturing companies throughout Europe.

Case Company $\mathrm{C}$ aims to perform the laptop remanufacturing process within 10 days from core arrival to delivery. All received cores arrive in specially designed containers and are stored in core Inventory until the Inspection process operation (see Figure 10).

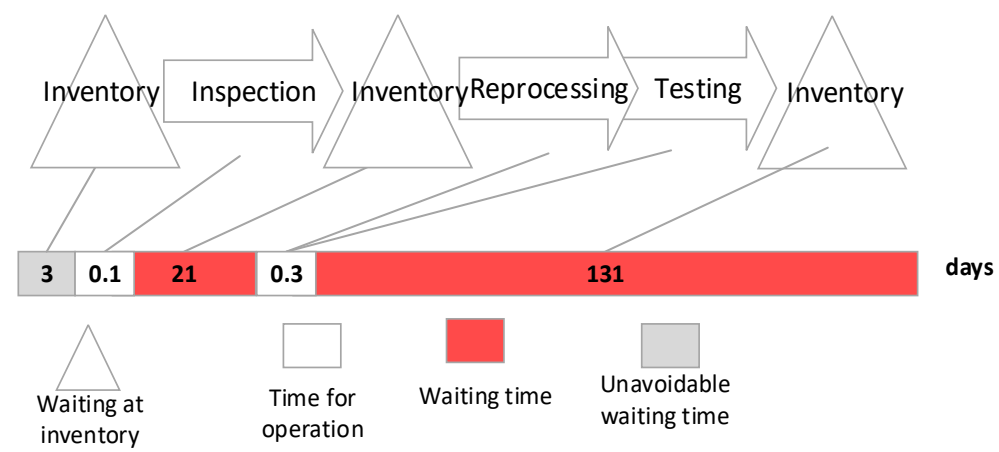

Figure 10: Process operations and process lead time at Company C.

During the core Inspection, the company registers the delivered cores, providing each arrival with an individual ID number, and initiates the product information collection process. During this operation, the sorting of cores through visual quality control is performed, removing any cores carrying lower value from the process. Additionally, accessories are separated from the main flow. The core registration is accomplished by uploading core information onto the company's intranet database, which displays core availability in the internal company's inventory stock. Then the cores are placed in an Inventory, waiting for the next process operation.

In the Reprocessing process operation, the case company tests the laptop and erases data. Simultaneously, core classification into four quality categories is performed, ranging from A, meaning top quality, to scrap, marked as D.

A - Top-quality product, fully functional with zero or insignificant cosmetic faults

B - Product has some minor functional problems and minor cosmetic faults

$\mathrm{C}$ - Product has significant functional problems and substantial cosmetic faults

D - Scrap 
For the top-quality laptops, the company performs additional steps under the Reprocessing operation: loading an image for better product representation to the customer, laptop polishing and cleaning, including from dust, replacement of hard disk or memory if needed, and packaging. Later, the remanufactured laptops are tested - in the Testing operation.

Customers can choose remanufactured laptops from the company's webpage, which displays the laptops in the finished goods Inventory. The main customers for A-category products are Swedish schools and municipalities. For the B and C-category products, which are sold abroad, the additional steps under the Reprocessing operation are not undertaken (a more comprehensive description of Company C's process can be found in appended Paper IV).

\subsubsection{REMANUfACTURING PROCESS AT COMPANY D}

Company $D$ is a contracted remanufacturer of filling machines (large machines that are typically used for liquid food and beverage packaging) and operates in a business-tobusiness environment, with a throughput of one to three machines per year. The company has long-term experience in the remanufacturing process. Every incoming filling machine follows a standard set of operations along the path towards upgrading to as-good-as-new functionality (see Figure 11).
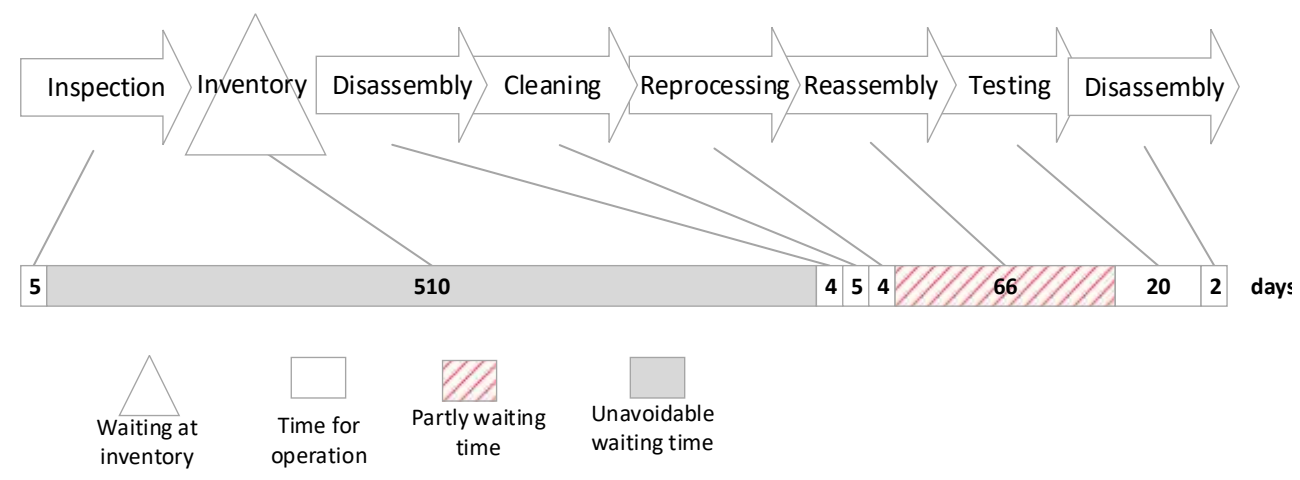

Figure 11: Process operations and process lead time at Company D.

During the Inspection process operation, the machine is controlled for absent parts. Moreover, the quality of parts is checked, followed by the analysis report and a document on the rebuilding kit. This is the process operation when the first visual inspection for defects is performed to evaluate the remanufacturing costs for the OEM. After reporting the machine information to the OEM, the core is stored $700 \mathrm{~m}$ away in an Inventory area until the order to initiate remanufacturing operations is confirmed, which can take up to three years in some cases. Due to the contracted agreement, there is a 100 per cent dependency on the OEM. 
The order from OEM is the signal to start the remanufacturing process, which usually takes between 15 and 20 weeks, depending on the core type.

After cores arrive back on the shop floor, Disassembly to a certain level is performed. Each machine is a single case and disassembly operators must determine for themselves the optimal disassembly level.

The Cleaning process operation is applied to the disassembled core parts, followed by Reprocessing and Reassembly operations.

During the Disassembly process operation, defects in the deep layers of the machine usually become evident; therefore, new spare parts are ordered for replacement during the Reassembly process operation. It is important to consider a bill of material (BOM) to ascertain that the parts planned for reuse, those that are missing, and the newly ordered spare parts match the original machine specifications. However, due to long delivery times for different spare parts, the Reassembly process operation becomes long. The mandatory process operation is Testing, which is a combination of several test methods. During this operation, the remanufactured filling machines are run for 20 days under different conditions to guarantee the required performance on the customer side.

After the final testing, the Disassembly operation begins, where the machine is disassembled to a certain level for transportation. The warranty period for remanufactured machines is six months and an additional performance warranty is provided. In terms of efficiency, the performance of the remanufactured machines is degraded by just one per cent compared to a new machine of the same generation (a more comprehensive description of Company D's process can be found in appended Paper V). 


\subsection{REMANUFACTURING PROCESS LEAD TIME}

In manufacturing, long process lead time typically causes considerable losses in companies' throughput and substantially increases the process costs. In remanufacturing, core acquisition and inventory holding costs tend to be low; this is why long lead time is tolerated. Long remanufacturing process lead time is observed at the four case companies (see Figure 12).

\section{Case Process \\ company lead time Distribution of the process lead time}

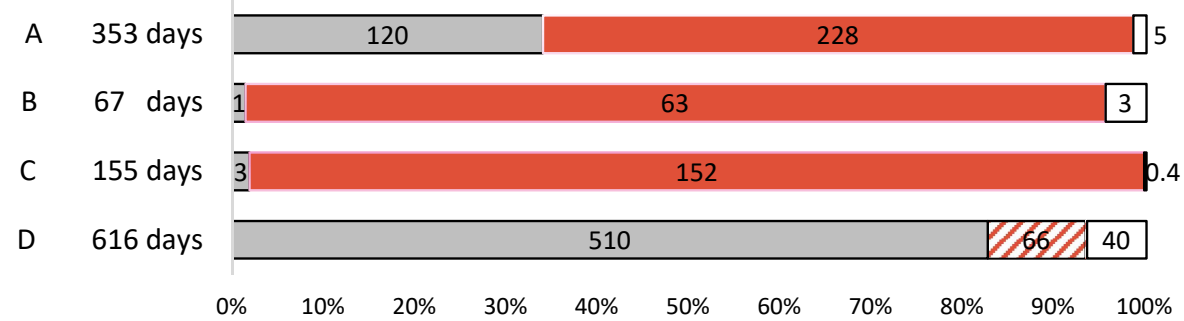

口Unavoidable waiting time $=$ Waiting time $\quad$ Partly waiting time $\square$ Time for operation

Figure 12: Process lead time distribution at case companies.

The lead time for the Company A is between five and 353 days; such a large variation of 348 days originates from waiting time, that could be avoided (marked in red colour) and unavoidable waiting time (marked in grey colour) (see Figure 12). If the unavoidable waiting time (which appears at core inventory, due to remanufacturers characteristic of low control over core) is eliminated, the waiting time, that could be avoided, attributes for the 98 per cent of the process lead time at Company A. A similar waiting time, that could be avoided, was discovered at Company B and C, accounting for 95 per cent and 99 per cent of process lead time, respectively. The waiting time at Company D is included in the Reassembly process operation, which accounts for 66 days. Some waiting time (four days) is typically spent on collecting spare parts. The Reassembly process step involves a large number of process tasks and has to be further investigated for waiting time separation from the time for operations.

The waiting times can also be divided into: waiting at inventory and waiting for order (see Table 7). 
Table 7: Waiting times at the case companies.

\begin{tabular}{|l|l|c|c|c|c|}
\hline \multicolumn{2}{|l|}{ Waiting time at the case companies (days) } & A & B & C & D \\
\hline $\begin{array}{l}\text { Waiting at } \\
\text { inventory }\end{array}$ & Waiting at core inventory (unavoidable waiting time) & 120 & 1 & 3 & 510 \\
\cline { 2 - 6 } & $\begin{array}{l}\text { Waiting at work-in-progress and finished goods } \\
\text { inventories }\end{array}$ & 208 & 0 & 152 & 0 \\
\hline $\begin{array}{l}\text { Waiting for } \\
\text { order }\end{array}$ & Waiting for core or spare part delivery & 15 & 63 & 0 & 4 \\
\cline { 2 - 6 } & Waiting for information on core & 5 & 0 & 0 & 0 \\
\hline Total & & $\mathbf{3 4 8}$ & $\mathbf{6 3}$ & $\mathbf{1 5 3}$ & $\mathbf{5 1 4}$ \\
\hline
\end{tabular}

Waiting at inventory: All four companies keep core inventories, however Company A and $\mathrm{C}$ hold also WIP and finished goods inventories that considerably prolong their process lead times (see Table 7). The most costly waiting time was found in the finished goods inventory, when the remanufactured products were waiting for customers' order. Company A belongs to the OEM sales department and holds ready-to-use remanufactured products in the finished goods inventory in order to enable better remanufactured product marketing and sales. However, sometimes the wrong type of products (not matching customer demand) appears in finished goods inventory creating useless resource utilization (see also Paper II).

Waiting for order: Long waiting time for core and/or spare part delivery prolongs process lead time at Company A, B and D (see Table 7). It was discovered that long waiting times for spare parts originated from insufficient connections with external suppliers as well as the absence of a Material Requirements Planning (MRP) system to control the material flow. Company A experiences a lack of information about the cores, combined with no core delivery information and usually an unknown supplier; this lack of information has caused operations to be stopped. Long waiting times for special spare parts were observed at Company B. All four companies maintain little or no cooperation with the other product life cycle stakeholders: product designers, OEMs, customers, service. Case companies use internal computerized communication systems, which do not satisfy employees' needs. Therefore, the only trusted information-sharing channel is verbal communication at meetings.

\subsubsection{PROCESS EFFICIENCY}

To estimate the process efficiency at the remanufacturing companies a simplified equation of the $3 b$ equation was used (see also Section 3.2.4).

$$
\text { Process ef ficiency }=\frac{\text { Time for value added operations }}{\text { Time for value added }+ \text { non value added operations }+ \text { Waiting time }}
$$


In the simplified equation of process efficiency, the time for value-added operations is replaced by the time for operations (both value-added and non-value-added ones). Simultaneously, process lead time, which consists of time for operations and waiting time, is subtracted with the unavoidable waiting time at the core inventory, due to remanufacturers' little control over the core.

$$
\text { Process efficiency }=\frac{\text { Time for operations }}{\text { Process lead time }- \text { unavoidable waiting time }}
$$

There are two reasons behind this simplification:

1) There is no data available on the time for value-added and non-value-added operations performed during the time for operations, since case companies do not measure the time for value-added and non-value-added operations;

2) The share of waiting time in process lead time is considerably larger than the time for operations, therefore the simplified equation does not cause any large deviation in process efficiency, compared to when the $3 \mathrm{~b}$ equation is used.

As a result, the process efficiency is below one per cent at companies A-C. Company D tends to have higher process efficiency; however, the 66 days, marked in a red-and-white lined pattern in Figure 12 and used for the Reassembly process operation, needs to be separated into time for operations and waiting time - this is to achieve a proper view on the case company's process efficiency.

\subsection{REMANUFACTURING PROCESS CHALLENGES THAT PROLONG PROCESS LEAD TIME}

Long lead times for the remanufacturing process are often the result of long waiting times, which account for 95-99 per cent of process lead times at three of the four case companies. The reason behind long process lead time originates from a high number of internal and external challenges (Hammond et al., 1998; Guide, 2000; Lundmark et al., 2009). Internal challenges typically originate from the remanufacturer's internal process operations, while external ones depend on the challenges outside the companies' borders.

To identify remanufacturing process challenges, three levels of remanufacturing challenges have been identified through a literature study: external challenges on industry- and system-levels, and internal challenges on a process-level (see Figure 13 and Paper VII).

- Industry level refers to the challenges related to the remanufacturing industry (economic, environmental and political perspectives)

- System level refers to the remanufacturing system (closed product life cycle system perspective)

- Process level refers to the remanufacturing process (the company's operations perspective). 


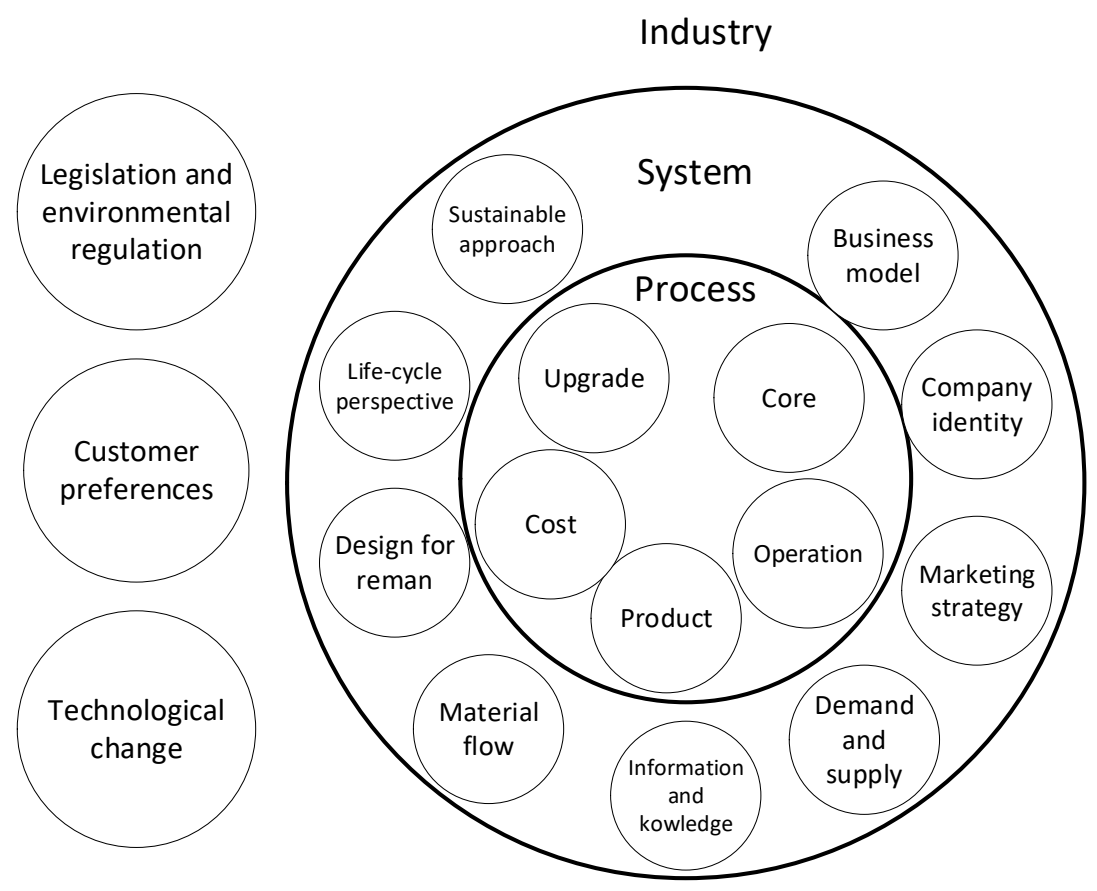

Figure 13: Three levels of remanufacturing challenges from the literature study (Paper VII).

Each of the industry-level challenges has a major effect on system-level challenges, while the system-level challenges mostly affect the process-level challenges. Five process-level challenges have been identified. As shown in Figure 13, these process challenges consider issues with the core, operation, remanufactured product, cost and upgrade:

Core challenges - process challenges that are related to the unpredictable and insufficient incoming core: quantity, quality, variability, and timing, with the main focus on core and spare part acquisition and management (see Zhang et al., 2014; Zhou et al., 2011; Wei et al., 2015; Wu et al., 2015; Hu et al., 2014; Hu et al., 2015; Inderfurth and Mukherjee, 2008; Inderfurth and Kleber, 2013; Gan and Su, 2009; Goodall et al., 2015; Clottey et al., 2012; Clottey and Benton, 2014).

Operation challenges - process challenges relating to unpredictable and long processing and waiting times, an unknown number of required operations in the process and process sequence, and a high level of inventory originating from the complex remanufacturing process (see Jin et al., 2013; Seliger et al., 2006; Kin et al., 2014; Zhou and Yu, 2014; Morgan and Gagnon, 2013; Priyono et al., 2015; Kang and Hong, 2012; Kellenbrink et al., 2014).

Product challenges - process challenges that affect the remanufactured product quality (Parkinson and Thompson, 2004; Wang and Chan, 2013; Hazen et al., 2012). 


\section{WITHIN REMANUFACTURING}

Cost challenges - process challenges dependent on cost fluctuations due to uncertainty about an acquired core's condition and the required process operations (Robotis et al, 2012; Graham et al., 2015; Mutingi et al., 2014).

Upgrade challenges - process challenges that are caused by an inability to comply with the customer's required innovation rate, which affects both the remanufactured product and the remanufacturing process. Product upgrade knowledge and process information are insufficient at remanufacturing (Behdad, 2011; Galbrethet al, 2013; Falconi et al., 2017).

Remanufacturing process challenges have also been studied at the four case companies. Through the case study approach, 10 process challenges associated with core and spare part delivery, materials and information flow management were identified (see Table 8).

Table 8: Cross case analysis of remanufacturing process level challenges that cause long lead times, identified at each company (" $\mathrm{x}$ " is applicable; "N/A" is not applicable).

\begin{tabular}{|c|c|c|c|c|c|}
\hline \multirow{2}{*}{\multicolumn{2}{|c|}{$\begin{array}{l}\text { Case companies' remanufacturing process } \\
\text { challenges }\end{array}$}} & \multicolumn{4}{|c|}{ Case Company } \\
\hline & & $\mathbf{A}$ & B & $\mathbf{C}$ & D \\
\hline 1 & Lack of material requirements planning system & $\mathrm{x}$ & $\mathrm{x}$ & $\mathrm{x}$ & $\mathrm{x}$ \\
\hline 2 & Poor information on cores & $\mathrm{x}$ & $\mathrm{x}$ & $\mathrm{x}$ & $\mathrm{x}$ \\
\hline 3 & Lack of cores & $\mathrm{x}$ & $\mathrm{x}$ & $\mathrm{x}$ & $\mathrm{x}$ \\
\hline 4 & Poor information on spare parts & $\mathrm{x}$ & $\mathrm{x}$ & $\mathrm{N} / \mathrm{A}$ & $\mathrm{x}$ \\
\hline 5 & Lack of spare parts & $\mathrm{x}$ & $\mathrm{x}$ & $\mathrm{N} / \mathrm{A}$ & $\mathrm{N} / \mathrm{A}$ \\
\hline 6 & Insufficient quality management practices & $\mathrm{x}$ & $\mathrm{N} / \mathrm{A}$ & $\mathrm{x}$ & $\mathrm{N} / \mathrm{A}$ \\
\hline 7 & Large inventories & $\mathrm{x}$ & N/A & $\mathrm{x}$ & $\mathrm{N} / \mathrm{A}$ \\
\hline 8 & Stochastic remanufacturing processes & $\mathrm{x}$ & N/A & N/A & $\mathrm{x}$ \\
\hline 9 & Lack of supply-demand balance & $\mathrm{N} / \mathrm{A}$ & N/A & $\mathrm{x}$ & $\mathrm{N} / \mathrm{A}$ \\
\hline 10 & Insufficient automation & N/A & N/A & $\mathrm{x}$ & N/A \\
\hline
\end{tabular}

The five process-level challenges from literature study were assessed regarding their effect on prolonging remanufacturing process lead time, emphasizing the core, operation, product, and upgrade process challenges (see Figure 13), that contribute most to the prolonging process lead time for remanufacturing. During the analysis of the case companies' process challenges, the first eight process challenges with the highest relevance to all four case companies (see Table 8), were selected to further investigation of their effect on prolonging remanufacturing process lead time. As a result, eight 
challenges were modified: joined together (No. 2: Poor information on cores and No. 4: Poor information on spare parts challenges; No. 3: Lack of cores and No. 5: Lack of spare parts challenges) and reformulated (through the broadening of the definition of the challenges to better suit the definitions from the literature study). The performed analysis of collected process challenges from literature and case studies lays the base for the classification to five remanufacturing process challenges that prolong remanufacturing process lead time:

1. Unpredictable core quality, quantity, and timing

2. Weak collaboration, information exchange, and miscommunication

3. High inventory levels

4. Unknown number of required operations in process and process sequence

5. Insufficient employee skills for process and product upgrade

A detailed description of the challenges can be found in the appended papers: for the literature study Papers I and VII are relevant, while the case study is mainly described in Papers II-VI.

\subsubsection{UNPREDICTABLE CORE QUALITY, QUANTITY, AND TIMING}

Due to the lack of remanufacturing control over the delivered cores, the issues associated with core availability, quality and timing, have the largest impact on remanufacturing process lead time. The availability of the right type of the core at the right time tends to be insufficient. In particularly, Company $\mathrm{C}$ pointed out fluctuations in the core delivery as their biggest challenge (for details see Paper IV).

The lack of core and spare parts, severe defects in the core and their tendency to arrive at unexpected times are also noticed at all the case companies. The quality of that core is sometimes inappropriate, which also contributes to long remanufacturing process lead time. These issues depend on the availability of information on core condition and delivery time from the previous user. Company A experiences a lack of information about core condition and delivery (see Paper II). Due to an unsynchronized core return process, the delivery time tends to be sporadic (see also Guide, 2000; Lundmark et al., 2009).

\subsubsection{WEAK COLLABORATION, INFORMATION EXCHANGE AND MISCOMMUNICATION}

The absence of strong employee collaboration and information-sharing channels, as well as a lack of internal and external communication, observed at four case companies, originate mostly from the distant relations between remanufacturers and OEMs (see also Phelan et al., 2000). Feed-forward information losses and feedback information bottlenecks are emphasized under this challenge and can be further read about in Paper VI. A non-existent, out-of-date, complex or non-flexible MRP system is an empirical evidence of a such challenge at each case company (see Table 8 and Paper VII). 


\subsubsection{High INVENTORY LEVELS}

High inventory levels are mainly a compensation for insufficient core quality. High inventory levels are also a response to unpredictable and uneven core delivery, where the inventory storage strategy is selected due to low core acquisition costs. This is observed to a large extent at Companies A and C (see Papers II and IV); The analysis of Company C's inventory revealed that the accumulated inventory storage time was nearly 380 times larger than the time for operations.

High inventory level contributes to the high level of uncontrolled inventory, which not only occupies considerable facility space, but also hinders the collection of necessary cores, spare parts or remanufactured products. This inventory challenge is attributed to the management of inventory storage space in Companies A and C, where the overloaded inventory causes problems in finding the right item. The wrong type of remanufactured products (not matching customer demand) in finished goods inventory was observed at Company A, and missing parts on the kitting trolley are a typical problem at Company B. A lack of spare parts and long storage time at the external suppliers are experienced by Company C (see Paper III), where process capacity is limited by inadequate information on core delivery to the remanufacturer. However, high inventory levels are tolerated by all four companies due to the low costs of inventory acquisition and holding in the storage. However, as mentioned previously in this thesis, according to Ohno (1988) and Ahlstrom (1997) inventory, is the most dangerous source of waste, since it conceals problems.

\subsubsection{UNKNOWN NUMBER OF REQUIRED OPERATIONS IN PROCESS AND PROCESS SEQUENCE}

Since every single core arrives in a different condition, a different number of different operations have to be performed to bring that item to as-good-as-new functionality (see Paper VII). The absence of standard operations, a standard bill of material, and a standard list of assembly steps, along with incomplete or missing documentation/instructions for the operator to perform the assembly, are the reasons for unclear operations and unknown tasks, which is especially apparent at Company D (see Paper V).

\subsubsection{INSUFFICIENT EMPLOYEE SKILLS FOR PROCESS AND PRODUCT UPGRADE}

This challenge relates to the lack of application of quality standards to the processes, as well as the lack of employee qualifications in defining the possibility of upgrading products. Product upgrade is a growing challenge due to the technological advances and variations in the cores and spare parts (see also Behdad and Thurston, 2011; Galbreth et al., 2013). In the four case companies this challenge comes along with the need to cooperate with OEMs to develop the absent disassembly and remanufacturing instructions. 
PROCESS LEAD TIME CHALLENGES

LEAN REMANUFACTURING

WITHIN REMANUFACTURING 


\section{LEAN PRACTICES TO ADDRESS}

\section{REMANUFACTURING PROCESS LEAD TIME}

\section{CHALLENGES}

This chapter presents lean practices to address the remanufacturing process challenges that prolong process lead time. Similarly, as in the previous chapter, this chapter incorporates the results from both literature and case studies.

After the analysis of remanufacturing process challenges that prolong process lead time for RQ1, the matching lean practices to remanufacturing challenges was carried out to answer RQ2 (see Table 9 and Paper VII). It was noted that the conceptual development of lean for remanufacturing dominates over the descriptive case on the application of lean tools and practices to remanufacturing companies. Sundin (2006) has identified remanufacturing need work with lean to lower the high level of inventories and improve material movements, product flow, and use of space. Jacobs and Chase (2001) presented lean as a waste reduction strategy. However, majority of lean remanufacturing researchers highlight two lean practices: pulling production flow through kanban ordering system (see for example Guide, 2000; Kanikula and Koch, 2011) and facility layout transformation to cellular layout (see for example Hunter and Black, 2007). Additionally, some researchers have succeeded in demonstrating positive effect of lean tools on remanufacturing process (see Section 3.4 and also Fargher, 2006; Kucher, 2008). 
In this thesis the matching of the lean practices to remanufacturing process challenges is based on the data collected during the focus group interviews at case companies and the lean practices from Table 4 that have the greater positive effect on the process lead time reduction (see Section 3.2.3). The focus group participants had to discuss the possible improvements to the identified process challenges at each case company. The collected improvements were prioritized (for details on data collection session see Section 2.3.1) and further aligned to the lean practices from literature study (see Table 4). As the result, six lean practices to reduce remanufacturing process lead time are suggested to case companies: product families, kanban, layout for continuous flow, cross functional teams, standard operating procedures and supplier partnerships (see Table 9).

Table 9: Lean practices to address remanufacturing process challenges that prolong remanufacturing process lead time.

\begin{tabular}{|c|c|c|c|c|c|c|}
\hline \multirow[t]{2}{*}{$\begin{array}{l}\text { General } \\
\text { improvements }\end{array}$} & \multirow{2}{*}{$\begin{array}{l}\text { Selected lean } \\
\text { practices with a } \\
\text { positive effect on } \\
\text { remanufacturing } \\
\text { process lead time }\end{array}$} & \multicolumn{5}{|c|}{$\begin{array}{l}\text { Remanufacturing process challenges that } \\
\text { prolong remanufacturing process lead time }\end{array}$} \\
\hline & & 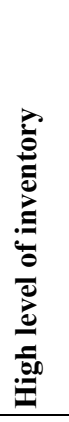 & 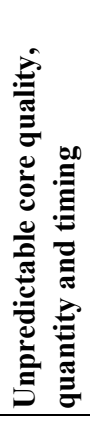 & 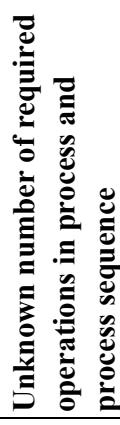 & 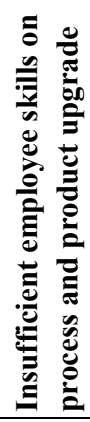 & 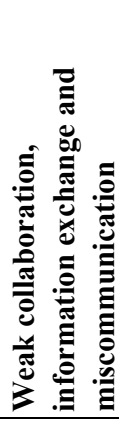 \\
\hline \multirow{2}{*}{ Process and layout } & Product families & & $\mathrm{X}$ & $\mathrm{X}$ & & \\
\hline & $\begin{array}{l}\text { Layout for } \\
\text { continuous flow }\end{array}$ & $\mathrm{X}$ & & & & $\mathrm{X}$ \\
\hline \multirow{2}{*}{$\begin{array}{l}\text { Product delivery: } \\
\text { internal and } \\
\text { external from } \\
\text { suppliers and to } \\
\text { customers }\end{array}$} & Kanban & $\mathrm{X}$ & $\mathrm{X}$ & & & $\mathrm{X}$ \\
\hline & $\begin{array}{l}\text { Supplier } \\
\text { partnerships }\end{array}$ & & $\mathrm{X}$ & & $X$ & $\mathrm{X}$ \\
\hline $\begin{array}{l}\text { Employee } \\
\text { commitment and } \\
\text { management }\end{array}$ & $\begin{array}{l}\text { Cross functional } \\
\text { teams }\end{array}$ & & & $\mathrm{X}$ & $X$ & $X$ \\
\hline $\begin{array}{l}\text { Quality } \\
\text { management }\end{array}$ & $\begin{array}{l}\text { Standard Operating } \\
\text { Procedures }\end{array}$ & & & $\mathrm{X}$ & $X$ & \\
\hline
\end{tabular}




\subsection{PRODUCT FAMILIES}

One of possible lean practice to remanufacturing challenges that prolong lead time is the classification of the received cores to product families (see Case Company A and C). The classification to product families is based on the similar criteria as in manufacturing (see Section 3.2.3) however adding the criteria of the incoming core quality and/or the desired by customer remanufactured product quality.

As a result, two types of product families need be introduced in remanufacturing: core product family and remanufactured product family. During the Inspection process operation, the core is classified to the core product family, ranging from A - the best quality to D - scrap. Typically, when the customer places an order for the remanufactured product type and needed quality/performance, the corresponding core, that match the required product quality, is withdrawn for the remanufacturing process. However, sometimes, the demanded product quality is not matching the available core quality. In this case, during the remanufacturing process the initial core classification to core product family could be adjusted to match the customer desired remanufactured product performance (see next Section 5.2). The remanufactured product family is based on the desired product quality/performance demanded by the customer: A, B, C and D (see Figure 14):

- A - as-new quality/product performance - fully functional product with zero or insignificant cosmetic faults

- $\mathrm{B}$ - high-quality/product performance - a product that has some minor functional problems and minor cosmetic faults

- $\mathrm{C}$ - moderate-quality/product performance - a product that has significant functional problems and substantial cosmetic faults

- D - scrap

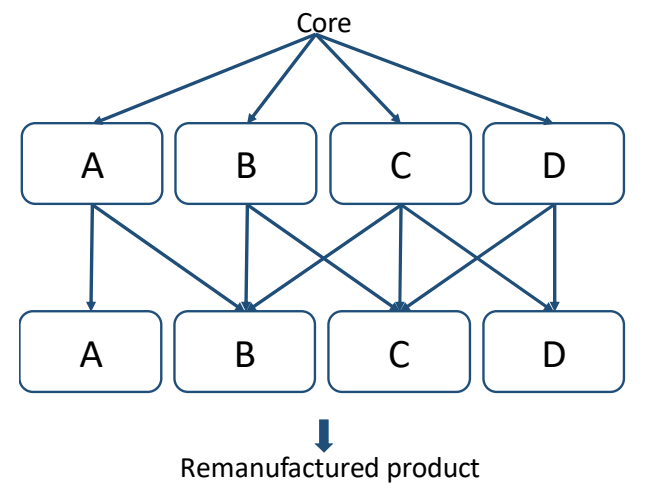

Core product family Remanufacturing process Remanufactured product family

Figure 14: A possible transition from core product family to remanufactured product family through a remanufacturing process. 
Classification to product families would imply defining the frames for cores that arrive in unique condition. This grouping would enable better control of the remanufacturing operations. Since the remanufacturers' process challenge of an unknown number of required operations in process is linked to core quality, remanufacturing could benefit from this lean practice.

However, due to the large variation in core quality, the number of product families in remanufacturing would be several times larger than in manufacturing. For each product in manufacturing, there might be four product families in remanufacturing (see also Section 4.1.4).

In some cases, products that belonged to different product families in manufacturing could be grouped into the same product family in remanufacturing (for example, product family A). Yet, thanks to low production volumes, remanufacturers can manage the required process operations for each group of product families.

As a result, remanufacturing process operations are devoted to a certain type of product family. A clear process flow with a defined process capacity and a dedicated employee team are a few of the benefits associated with product families. Therefore, this lean improvement reduces process complexity, controls process capacity, and strengthens the communication between operators and with OEMs. Consequently, the process lead time will be linked to the specific product family, making the process lead time shorter and more predictable (for more details on the benefits of Product Families to Case Company A and C, see Paper IV).

\subsection{KANBAN}

Kanban, originating from the literature on lean manufacturing (see Section 3.2.3), is another possible lean practice to remanufactured process challenges with a positive impact on process lead time. Case Company B (see Section 4.1.3) has the most suitable prerequisites for establishing the kanban ordering system among the four case companies: due to its contracted agreement with OEM regarding a stable supply and demand.

However, the remanufacturing customers' demand does not always match the types of cores retrieved. To adopt their processes to customer demand, remanufacturing companies need an adjusted kanban ordering system. Thanks to an adjusted kanban, remanufacturers will have the possibility to pull products that customers are willing to buy as late as from the core inventory. A unique capability of remanufacturing companies to adjust the number of products in product families A, B, C or D based on real customer demand is implicit in the nature of the remanufacturing process, which is demonstrated in Figure 15. The development of an adjusted kanban is based on Case Companies A and C. 


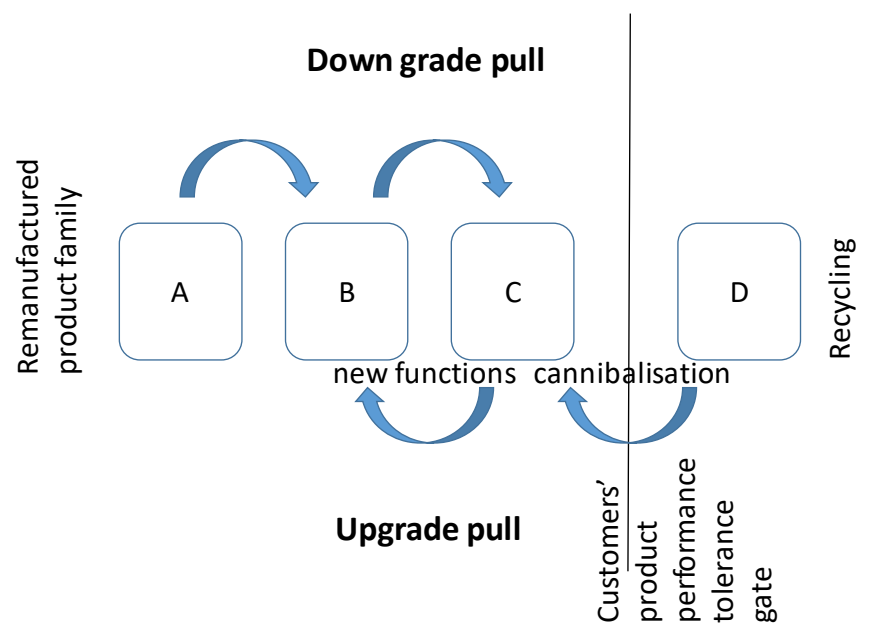

Figure 15: Two types of late product pull from core inventory: down grade and upgrade pull.

Two options for late pull according to customer demand are depicted in Figure 15. The down grade pull implies no action on the core in order to adjust its initial quality to the desired level of performance. The down grade pull releases the demanded products according to the following order: A-product category goes over to B, and B goes to C. This down grading is a reasonable measure to cope with customer demand and its mismatch with the retrieved cores. Another late pull option is to upgrade, meaning product part cannibalization, when several products from D-product family are used to create one $\mathrm{C}$ product. Installing new functions to a $\mathrm{C}$ product allows it to turn into $\mathrm{B}$ product performance. It has been noted that going from B to A would require unnecessary investment and therefore is not presented as an option for late pull.

Kanban will address the challenges posed by a high level of inventory and weak collaboration, information exchange and miscommunication. As a result, a kanban ordering system contributes to the elimination of waiting times associated with waiting for cores or spare parts and consequently reduces process lead times at the remanufacturing company (for details on kanban benefits for case companies, see Papers III, IV, and VII).

\subsection{LAYOUT FOR CONTINUOUS FLOW}

Working in a remanufacturing facility where process operations are isolated by a distance or separated by a physical wall considerably prolongs process lead time. Therefore, changing a disrupted process layout to a layout allowing continuous flow is the third suggested lean practice that enables process-lead-time reduction. One possible way to achieve layout for continuous flow is to employ a cellular layout (see Section 3.2.3 and Figure 16). 


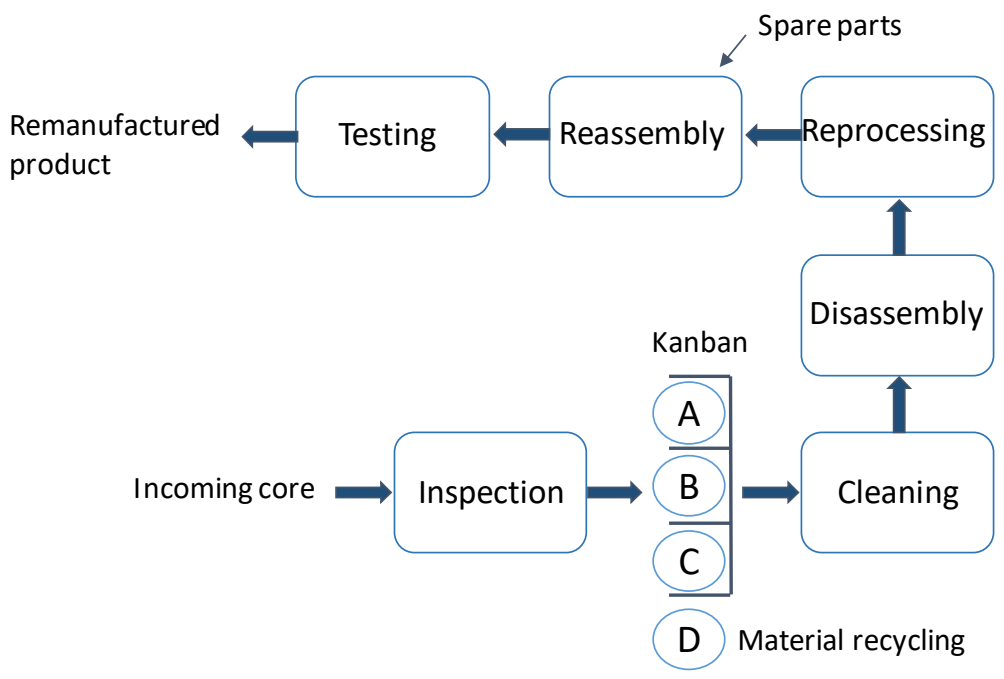

Figure 16: Cellular layout for remanufacturing process operations.

Figure 16 shows a cellular layout for six remanufacturing process operations (see Section 3.4 and in particular Figure 6). A kanban ordering system with the core product families is placed directly after the core Inspection operation and before the customer order is placed. To meet customer demand, a suitable core from kanban is collected for the following process operations: Cleaning, Disassembly, Reprocessing, Reassembly and Testing. Therefore, a new layout makes the process capacity more flexible in responding to customer demand. The physical location for each process operation is developed according to the "C" or "U" shape to avoid excessive material transportation and workin-progress (WIP) inventory. A cellular layout with small batches ensures quicker control over the arriving cores, providing rapid feedback to the core supplier. A cellular layout allows quick adjustments in the number of employees at the work stations and facilitates learning about the operations performed by the operator in the cross functional teams (see next Section 5.4).

More importantly, a cellular factory layout for continuous flow is beneficial in terms of solving high inventory levels challenge and, together with a kanban ordering system, has the greatest effect on lead-time reduction (for an example of cellular layout at Case Company C, see also Paper IV).

\subsection{CROSS FUNCTIONAL TEAMS}

Work in cross functional teams means improving teamwork by introducing product teams according to the product families (see Section 5.1). Creating teamwork throughout the factory is beneficial in controlling core and spare part delivery, since improved information sharing enables in-time ordering of spare parts and the planning of required 
operations. Cross functional teams are responsible for the product from core arrival to shipment to the customer, enabling quick feedback (for more details on this lean practice, see Paper V). This facilitates a greater reduction in variations in lead time by providing what is needed when it is needed.

Grouping employees into dedicated product teams is a possible solution to managing shop-floor tasks at the case companies. According to Case Company B's production manager, today only the managerial staff work in a team. He emphasizes the importance of task delegation to the teams of shop-floor employees in order to increase their participation in the customer-supplier relationship. The production manager continues that this empowerment would let the team to know what customers are buying and enable them to talk to suppliers.

Cross functional teams enable smoother employee learning and knowledge exchange, and quicker problem solving. Training through problem solving in order to exchange experiences, gain knowledge in the related area, or establish networking to generate the missing data is vital for all four remanufacturing companies, since remanufacturers are currently very dependent on manual work (for details, see Paper V). Improved teamwork through the introduction of cross functional teams would contribute to lead-time reduction by delivering the right product at the required time.

\subsection{STANDARD OPERATING PROCEDURES}

To compensate for the lack of product information from OEMs, remanufacturing companies are advised to develop their own standard operating procedures. These procedures should involve instructions and checklists based on the best remanufacturing experience (see Section 3.2.3), starting with the development of standard operating procedures for a selected product family. By applying standard operating procedures to shop-floor operations dedicated to specific product families, the challenges of an unknown number of required operations in the process and process sequence as well as insufficient employee skills for process and product upgrade can be reduced (for details on the application of Standard Operating Procedures to Case Company D, see Paper V). Consequently, standard operating procedures would help to reduce lead time and its variation and improve remanufacturing process efficiency.

\subsection{SUPPLIER PARTNERSHIPS}

Developing supplier partnerships is vital for remanufacturing due to the weak collaboration and information exchange with OEMs (Lund, 1983; Östlin et al., 2008). Developing supplier partnerships (see Section 3.2.3) is an essential element of the continuous improvement in lean, leading to the generation of partnering relations with OEMs. The effect of this lean practice can be observed through the entire remanufacturing process in the improved supply of cores and spare parts with the feedback provided (for details of supplier partnerships, see also Paper V). 
Partnering with suppliers to develop long-term sustainable relationships benefits remanufacturing, but also OEMs. For example, due to Case Company B's agreed contract, the supply and demand for remanufactured products is relatively stable and predictable. Since the condition of the incoming core plays a key role in determining the process lead time, building a trustworthy relationship in the form of a contract is a suitable means to reduce the risk associated with core condition. Finally, the OEM benefits by receiving the demanded remanufactured product on time and in the right quality and quantity. 


\section{DISCUSSION}

The Discussion chapter is divided into three parts: 1) discussion of the process lead time challenges within remanufacturing; 2) discussion of lean practices to address remanufacturing process lead time challenges; and 3) reflection on the research method. The first two parts of this chapter is the analysis, comparison and merging of the research results to address the research questions and objective.

The last part of this chapter is dedicated to a reflection on the data collection and analysis methods, as well as the validity, reliability, and generalizability.

\subsection{PROCESS LEAD TIME CHALLENGES WITHIN REMANUFACTURING}

The purpose of the discussion of the research results is to argue for suitable lean practices to address remanufacturing process challenges and reduce process lead time. The research questions "What?", and "How?" will be answered here.

The first Research Question was: "What are the process challenges for remanufacturing that prolong process lead time?" This thesis has identified the largest cause for long process lead time at three of four case companies to be the waiting times, that could be avoided, which account for 95-99 per cent of the process lead times at three of four case companies. The reason for long lead time, and in particular long waiting time, is reflected in five remanufacturing process challenges (see Section 4.3 and Figure 17). 


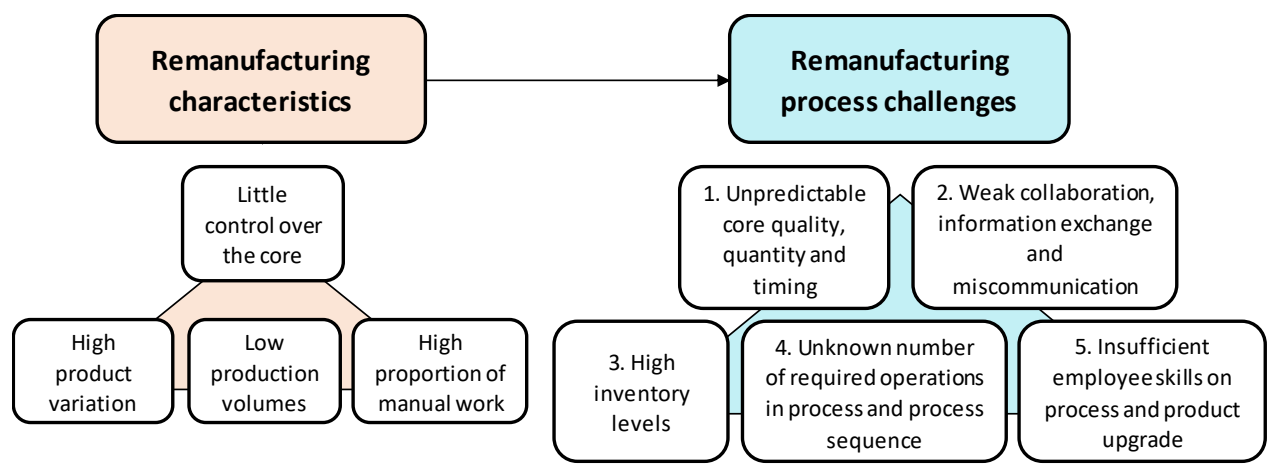

Figure 17: Relation between remanufacturing characteristics and process challenges that prolong process lead time (Hammond et al., 1998; Steinhilper, 1998; Guide, 2000; Seitz and Peattie, 2004; Östlin et al., 2009; Lundmark et al., 2009).

Figure 17 emphasizes that remanufacturing process challenges that prolong process lead time arise partly from the unique remanufacturing characteristics: little control over the core, low production volumes, high product variation, and a high proportion of manual work. These five remanufacturing process challenges that prolong remanufacturing process lead time are:

1. Unpredictable core quality, quantity, and timing: Due to the lack of remanufacturing control over the delivered cores, the challenges associated with core availability, quality, and timing have the largest impact on remanufacturing process lead time. Coping with unpredictable core quality, quantity, and timing is one of the greatest challenges for remanufacturers.

2. Weak collaboration, information exchange, and miscommunication: This process challenge is also closely connected to the remanufacturing characteristic of little control over the core. Managing internal and external collaboration, information exchange, and communication is another great process challenge that remanufacturers face today.

The two first mentioned process challenges impact upon the three remaining process challenges. These three process challenges originate also from the remanufacturing characteristics of high product variation, low production volumes, and a high proportion of manual work, when compared to manufacturing (see Figure 17).

3. High inventory levels: Dealing with a high variation in core delivery and mismatch between the demanded remanufactured product quality and available core quality, remanufacturers tend to keep large core, WIP and finished goods inventories. To control the level of inventory, in particularly WIP and finished goods inventories, remains one of the greatest challenges for today's remanufacturers. 
4. Unknown number of required operations in the process and process sequence: Every core requires a different number of operations to be performed to bring the core to the product quality/performance that the new customer ask for. To cope with the unknown number of required operations and process sequence for a great variety of remanufactured products is a challenge for remanufacturer.

5. Insufficient employee skills for process and product upgrade: This challenge relates to the lack of application of quality standards to the processes, as well as the lack of employee qualifications regarding product upgrade. Due to little support from the OEM this challenge tends to escalate, especially when remanufacturing is performed by an independent remanufacturer (IR).

\subsection{LEAN PRACTICES TO ADDRESS REMANUFACTURING PROCESS LEAD TIME CHALLENGES}

The second Research Question was: "How can the process challenges that prolong process lead time be addressed by lean?" The need to reduce waiting time in remanufacturing, especially the one that can be avoided, originates from the need to reduce remanufacturing process lead time in order to make process more efficient and increase the number of remanufactured products.

This thesis approaches lean as an improvement strategy to reduce remanufacturing process lead time, while adjusting the lean practices according to the four characteristics of remanufacturing (see Figure 17). Six lean practices to address the remanufacturing process challenges and to reduce remanufacturing process lead time are suggested in this thesis:

1. Product families: The desired process lead time reduction due to core classification to product families emphasizes the need to change the core Inspection process operation. The better the analysis and classification into product families, the more substantial the reduction in process lead time that can be expected. The main difference between manufacturing and remanufacturing is the degree of classification, implying that, for every type of manufactured product, remanufacturing can specify several product families, where the classification is also based on incoming core quality and/or required by the customer remanufactured product quality (see Section 5.1).

2. Kanban: The transformation to a kanban ordering system is a long-term vision for some remanufacturing industries. However, based on Case Company B, one of the leaders in a car engine remanufacturing, kanban can be a suitable practice to reduce lead time in remanufacturing. Additionally, positive remanufacturing prerequisites for late pull (down grade and upgrade) from core inventory have been revealed in accordance with an adjusted kanban (see Section 5.2 and Figure 15). Case 
Companies $\mathrm{A}$ and $\mathrm{C}$ use down grade and upgrade pull strategies in order to satisfy customer demand. This ability to quickly respond to customer demand at the beginning of the remanufacturing process could become the competitive advantage of remanufacturing.

These two mentioned lean practices have been adjusted to remanufacturing characteristics, however most lean practices could be used for remanufacturing without any changes, however considering the classification to product families:

3. Layout for continuous flow: The lean practice of changing the process layout to permit continuous flow can be applied at remanufacturing companies. In comparison to highly automated manufacturing, where relocation of some machines and infrastructure is not reasonable, remanufacturers do not face this issue due to little automation and a high proportion of manual work.

4. Cross functional teams: Creating teams, that are responsible for the remanufacturing process from core arrival from supplier to remanufactured product shipment to customer, is the focus of this lean practice. Delegating responsibility for the process to a team would enable employee collaboration and stimulate the development of improvements to overcome process challenges.

5. Standard operating procedures: The importance of standard operating procedures is as high in remanufacturing as in manufacturing, with the difference that, in addition to assembly instructions, remanufacturers need to develop disassembly and other relevant standards and checklists for each product family.

6. Supplier partnerships: This is one of the most important lean practices that can contribute to waiting time reduction. Including suppliers and customers in remanufacturing operations is the key to a supplier partnerships practice.

After an implementation of the suggested lean practices, the potential reductions in process lead time could be projected onto the case companies. A potential reduction is caused by the reduction in waiting time, that could be avoided, as the effect of lean practices to the process challenges that prolong process lead time. Apart from lead time reduction, other areas, which the six lean practices contribute to, are: remanufactured product delivery, quality management, process and layout improvements, and employee communication and management (see Table 9). 


\subsection{REFLECTION ON THE RESEARCH METHOD}

\subsubsection{DATA COLLECTION AND ANALYSIS METHOD}

The need to study remanufacturing process challenges in order to reduce process lead time was determined by the need to make remanufacturing more efficient. In order to understand and describe the complexity of the underlying issue, both literature and case studies were undertaken. The theoretical pre-understanding of remanufacturing process challenges originates from the literature study, that enables the further investigation and analysis of RQs at the case companies.

The data collection methods used during the case study were found to be suitable to gather the data on process lead time and associated challenges. During the case study, the focus was further narrowed to the process challenges that contribute to long process lead time at four case companies. The focus group interview was selected as the key data collection method due to the need to learn details from the viewpoint of employees engaged in the remanufacturing process. The Value Stream Mapping (VSM) tool, used during the focus group interviews, enabled the visualization of challenges along the remanufacturing process and its lead time, and stimulated the development of possible improvements. Focus group interviews combined with VSM helped in assessing process lead time. The constructive discussions during focus group interviews led to a group consensus on each focus group interview question. However, the biggest advantage of the focus group interview is reduced complexity when a broad variety of issues on process lead time are covered during one data collection session.

The other two data collection methods applied at each case company were a questionnaire and observation. The questionnaire provided an opportunity for the remanufacturer to prepare in advance and collect the necessary statistical data from their daily operations. Observation of shop-floor operations contributed to a better understanding of the remanufacturing process by the researcher.

The same data collection methods were applied to each of the four case companies, which enabled cross case analysis and strengthened data comparability. The strengths, weaknesses, opportunities, and threats of the case study approach are presented in Table 10. 
Table 10: SWOT analysis of case study approach.

\begin{tabular}{|c|c|}
\hline Strengths & Weaknesses \\
\hline $\begin{array}{l}\text { - Easy to collect data and compare among the } \\
\text { four case companies } \\
\text { - Integrates viewpoints on the process } \\
\text { challenges from employees within different } \\
\text { functions in the company } \\
\text { - Collects process challenges, that prolong } \\
\text { lead time, and possible improvements from } \\
\text { the employees' viewpoint } \\
\text { - Dialogues during the focus group interviews } \\
\text { provide a deeper understanding of the } \\
\text { underlying issues } \\
\text { - Visual VSM tool enables greater } \\
\text { understanding of the issues among the } \\
\text { participants } \\
\text { - Data triangulation is obtained from multiple } \\
\text { sources such as a questionnaire, observation, } \\
\text { and a focus group interview }\end{array}$ & $\begin{array}{l}\text { Dialogues during focus group interviews } \\
\text { have to be recorded and later transcribed, } \\
\text { since the researcher has no opportunity to } \\
\text { take notes } \\
\text { - Focus group participants are selected in } \\
\text { advance by the company's manager, which } \\
\text { can influence the findings } \\
\text { - The case study focuses on the process lead } \\
\text { time and challenges of one remanufactured } \\
\text { product } \\
\text { - Managerial participants tend to dominate } \\
\text { over shop-floor employees during the focus } \\
\text { group interviews }\end{array}$ \\
\hline Opportunities & Threats \\
\hline $\begin{array}{l}\text { Flexible in application to different industrial } \\
\text { companies, organizations, and within } \\
\text { academia }\end{array}$ & $\begin{array}{l}\text { - Bias in conducting focus group interviews } \\
\text { might influence the results } \\
\text { - The collected data on process lead time and } \\
\text { its challenges can vary due to different } \\
\text { circumstances and participants }\end{array}$ \\
\hline
\end{tabular}

An accurate statistical data on the process lead time distribution, in particularly, the distribution between the time for value-added operations and non-value-added ones could be collected using a complementary data collection method and/or prolonging the time researcher spend at the case companies. More research would have been needed to get a detailed description of the process lead time challenges at the case companies; however, the data collection methods described in this thesis fulfill the need for an overall study of the remanufacturing process challenges that prolong remanufacturing process lead time and reduce process efficiency. 


\subsubsection{VALIDITY AND RELIABILITY, AND GENERALIZABILITY}

As illustrated in Table 10, data triangulation was obtained from multiple sources such as a questionnaire, observation, and a focus group interview. Using the same data collection methods at each case company guaranteed method and result repeatability and reliability. Moreover, the achieving of research validity was reinforced during the feedback sessions with participating companies. The detailed description of the data collection process and findings enables generalizability of the research where the force of example (see Flyvbjerg, 2006) through case study is highlighted (for details on strategies employed in this thesis to approach research validity, reliability and generalizability see Section 2.4). 


\section{CONCLUSION}

This chapter demonstrates the novelty of the research performed and its delivered value. The emphasis is concentrated on the theoretical and practical implications of this research. This chapter concludes with recommendations to academia and industry for future work.

Remanufacturing plays an important role in the Circular Economy. In particular, remanufacturing process lead time becomes crucial in the aspiration to make the process more efficient and economically attractive to remanufacture more products. However, as this thesis has shown, long remanufacturing process lead time is caused by challenges which arise partly from the unique characteristics of remanufacturing. These characteristics are: little control over the core, high product variation, low production volumes, and a high proportion of manual work (see Figure 17). These unique characteristics make remanufacturing different from manufacturing; therefore, there is a need to define whether lean, widely used in manufacturing, can address remanufacturing process challenges in order to reduce process lead time. Thus, it is important to understand the challenges behind the long and inefficient remanufacturing process.

This thesis examines the nature of the remanufacturing process by separating remanufacturing process lead time into the time for operations and waiting time, while the waiting time is further divided into unavoidable waiting time and waiting time that could be avoided. The analysis of four companies' process lead times provided the basis for considering waiting time, that could be avoided, to be the key contributor to the long process lead time in remanufacturing, accounting for 95-99 per cent at three of the four companies. 
This thesis has expanded knowledge on: a) remanufacturing process challenges, that prolong remanufacturing process lead time, and b) lean practices to address these challenges. Based on the results from the literature and case studies, five remanufacturing challenges, that prolong remanufacturing process lead time, were identified and six lean practices to reduce remanufacturing process lead time were suggested.

The five remanufacturing process challenges are:

1. Unpredictable core quality, quantity, and timing

2. Weak collaboration, information exchange, and miscommunication

3. High inventory levels

4. Unknown number of required operations in process and process sequence

5. Insufficient employee skills for process and product upgrade

The six lean practices to address these challenges are:

1. Product families

2. Kanban

3. Layout for continuous flow

4. Cross functional teams

5. Standard operating procedures

6. Supplier partnerships

The relation between which lean practice that match each remanufacturing process is shown in Table 9.

The novelty of this thesis is the description of how lean, which is usually used for manufacturing companies, can be used in another complex process - remanufacturing. This thesis contributes to the knowledge on how lean could reduce remanufacturing process lead time. However, successful application of the suggested improvements is a long-term learning process.

\subsection{CONTRIBUTION TO ACADEMIA}

Lean is considered to be most suitable for high-volume and low-variety processes; however, this thesis has demonstrated that lean can also be suitable for low-volume and high-variety processes.

This thesis contributes to a better understanding of the remanufacturing process challenges that prolong remanufacturing process lead time and how these challenges can be tackled using lean. Therefore, knowledge about remanufacturing process operations, remanufacturing process lead time, time for operations, unavoidable waiting time, waiting time that could be avoided, and associated process challenges has been expanded. Furthermore, within this thesis it is discussed how the identified remanufacturing process challenges can be addressed by applying practices used in lean manufacturing. Thereby, the contribution of this thesis is the expanded knowledge of how lean could be applied in 
the remanufacturing context. Moreover, within this thesis some suggested lean practices are adjusted to suit remanufacturing characteristics, creating new knowledge about lean.

\subsection{CONTRIBUTION TO INDUSTRY}

In this thesis, four remanufacturing companies within diverse sectors, different relations with OEM and remanufacturing strategies were studied. All case companies experienced the problem of a long process lead time and the results point to five similar process challenges. This thesis suggests concrete lean practices to tackle these remanufacturing process challenges in order to reduce process lead time in remanufacturing. The thesis is of interest to different remanufacturing companies facing similar challenges and is an inspiring source for managers who are interested in the application of lean to remanufacturing. Moreover, other sectors than remanufacturing industries, which share any of the four remanufacturing characteristics, might find suitable lean practices for their remanufacturing process challenges.

\subsection{FUTURE WORK}

Improving remanufacturing process operations by using lean is a long-term goal in the area of lean remanufacturing. More research will be needed on the six suggested lean practices to address remanufacturing process challenges and reduce process lead time. These six suggested lean practices need to be tested and verified at remanufacturing companies. Studying lean practices in other than manufacturing companies is a possible alternative to the traditional lean school. Transferring the knowledge on lean practices between remanufacturing companies is a future task where researchers will become a valuable resource. 


\section{REFERENCES}

Aagard-Nielsen K. and Svensson L. (2006). Action Research and Interactive Research: Beyond Practice and Theory, Shaker Publishing, Maastricht.

Acar Sesen B. and Mutlu A. (2014). An action research to overcome undergraduates' laboratory anxiety, ERPA, Procedia - Social and Behavioral Sciences, vol. 152, pp. 546-550.

Ahlstrom P. (1997). Sequence in the Process of Adopting Lean Production, Stockholm School of Economics, Stockholm.

All-Party Parliamentary Sustainable Resource Group (APSRG). (2014). Remanufacturing: Towards a Resource Efficient Economy, pp. 1-12, collected at: http://www.policyconnect.org.uk/apsrg/research on 05.02.2018.

Andersen P.H. and Kragh H. (2010). Sense and sensibility: Two approaches for using existing theory in theory-building qualitative research, Industrial Marketing Management, vol. 39, pp.49-55.

Barnett J.A. (1989). Focusing on residents, Journal of Property Management, vol. 10 (1), pp. 31-32.

Behdad S. and Thurston D. (2011). A Markov chain model to maximize revenue by varying refurbished product upgrade levels, Proceedings of the ASME 2011 International Design Engineering Technical Conferences \& Computers and Information in Engineering Conference, August 28-31, Washington, DC, vol. 9, pp. 951-959.

Bellenger D.N., Bernhardt K.L., and Goldstucker J.L. (2011). Qualitative Research in Marketing, Marketing classics press edition, American Marketing Association, Chicago, Illinois, USA.

Berg B.L., and Lune H. (2004). Qualitative Research Methods for the Social Sciences. Pearson, Boston, MA. 
Bergman B. and Klefsjö B. (2012). Kvalitet från behov till användning, Studentlitteratur, Lund. Bicheno J. and Holweg M. (2009). The Lean Toolbox: The Essential Guide to Lean Transformation, Production and Inventory Control, $4^{\text {th }}$ ed., Systems and Industrial Engineering (PICSIE) Books, Buckingham.

Bicheno, J. (2004). The New Lean Toolbox: Toward Fast, Flexible Flow, $3^{\text {rd }}$ ed. Systems and Industrial Engineering (PICSIE) Books, Buckingham.

Bouzon M., Taboada Rodriguez C.M., and de Queiroz A.A. (2012). Cell layout application in product recovery: A lean proposal to increase efficiency in remanufacturing. Chinese Business Review, vol. 11 (5), pp. 467-475.

Bryman A. (1989). Research Methods and Organization Studies. Unwin Hyman, London.

Bryman A. (2015). Social Research Methods. Oxford University Press, Oxford.

Campbell D.W. (1975). Degrees of freedom and the case study, Comparative Political Studies, vol. 8, pp. 178-193.

Carlo F.D., Arleo M.A., Borgia O. and Tucci M. (2013). Layout design for a low capacity manufacturing line: A case study, International Journal of Engineering Business Management, Special Issue on Innovations in Fashion Industry, 5 (35), pp. 1-10.

Centre for Remanufacturing and Reuse (CRR). (2007). An Introduction to Remanufacturing, collected at: www.oakdenehollins.co.uk on 05.02.2018

Clottey T. and Benton W.C. (2014). Determining core acquisition quantities when products have long return lags, IIE Transactions, vol. 46 (9), pp. 880-893.

Clottey T., Benton W.C., and Srivastava R. (2012). Forecasting Product Returns for Remanufacturing Operations, Decision Sciences, vol.43 (4).

Dennis P. (2002). Lean Production Simplified: A Plain-Language Guide to the World's Most Powerful Production System, Productivity Press, New York.

Duggan K. J. (2002). Creating Mixed Model Value Streams - Practical Lean Techniques for Building to Demand. USA, CRC press.

Eisenhardt K.M. (1989). Building theories from case study research, Academy of Management Review, vol. 14 (4), pp. 532-550.

Ellen McArthur Foundation. (2013). Towards the Circular Economy. In: Economic and Business Rationale for an Accelerated Transition, vol. 1.

Ellström P.-E., Eklund J., Kock H., Lindström L., and Melin U. (1999). Knowledge Creation Through Collaborative Research: An Emerging Model, Falun.

Evans D. and Kowanko I. (2000). Literature reviews: Evolution of a research methodology, The Australian Journal of Advanced Nursing: A Quarterly Publication of the Royal Australian Nursing Federation, vol. 18 (2), pp. 33-38. 
Falconi V., Sundin E., Colledani M., and Copani G. (2017). Key success factors for implementing upgrading remanufacturing, Proceedings of the $3^{\text {rd }}$ International Conference on Remanufacturing (I-COR), Linköping, Sweden, October 24-26, pp. 47-59.

Fargher J.S.W. Jr. (2006). Lean Manufacturing and Remanufacturing implementation tools, Missouri Enterprise, University of Missouri, Rolla, MO.

Field A. (2013). Discovering Statistics using IBM SPSS Statistics, Sage, Los Angeles, CA.

Flyvbjerg B. (2006). Five misunderstandings about case-study research, Qualitative Inquiry, vol. 12 (2), pp. 219-245.

Fullerton R.R., McWatters C.S., and Fawson C. (2003). An examination of the relationships between JIT and financial performance, Journal of Operations Management, vol. 21 (4), pp. 383-404.

Galbreth M.R., Boyac T. and Verter V. (2013). Product reuse in innovative industries, Production and Operations Management, vol. 22 (4), pp. 1011-1033.

Gan S. and Su C. (2009). Inventory Control for Remanufacturing System with Stochastic Product Returns, $16^{\text {th }}$ International Conference on Industrial Engineering and Engineering Management, 21-23 October.

Geertz C. (1973). The Interpretation of Cultures: Selected Essays, Basic Books, New York.

Gnanavel S.S., Balasubramanian V. and Narendran T.T. (2015). Suzhal - An alternative layout to improve productivity and worker well-being in labor demanded lean environment, $6^{\text {th }}$ International Conference on Applied Human Factors and Ergonomics (AHFE 2015) and the Affiliated Conferences, AHFE 2015, Procedia Manufacturing, vol. 3, pp. 574-580.

Goodall P., Graham I., Harding J., Conway P., Schleyer S. and West A. (2015). Cost estimation for remanufacture with limited and uncertain information using case based reasoning, Journal of Remanufacturing, vol. 5 (7).

Graham I., Goodall P., Peng Y., Palmer C., West A., Conway P., Mascolo J. E. and Dettmer F. U. (2015). Performance measurement and KPIs for remanufacturing, Journal of Remanufacturing, vol. 5 (10).

Groover M. P. (2008), Automation, Production Systems, and Computer-Integrated Manufacturing, Pearson.

Guba E.G., and Lincoln Y.S. (1994). Competing paradigms in qualitative research. Handbook of Qualitative Research 2, pp. 105-117.

Guide V.D.R. Jr. (2000). Production planning and control for remanufacturing: Industry practice and research needs, Journal of Operations Management, vol. 18 (4), pp. 467-483.

Hammond R., Amezquita T., and Bras B. (1998). Issues in the Automotive Parts Remanufacturing Industry - A Discussion of Results from Surveys Performed among Remanufacturers, Systems Realization Laboratory, The George W. Woodruff School of Mechanical Engineering, Georgia Institute of Technology, Atlanta, GA, pp. 1-24. 
Hazen B. T., Overstreet R. E., Jones-Farmer L. A. and Field H. S. (2012). The role of ambiguity tolerance in consumer perception of remanufactured products, Int. J. Production Economics, vol. 135, pp.781-790.

Hu Y., Liu S., Lu H. and Zhang H. (2014). Remaining useful life assessment and its application in the decision for remanufacturing, Procedia CIRP 15, $21^{\text {st }}$ CIRP Conference on Life Cycle Engineering, pp. 212-217.

Hu Y., Liu S., Lu H. and Zhang H. (2015). Remanufacturing decision based on RUL assessment, Procedia CIRP 29, $22^{\text {nd }}$ CIRP Conference on Life Cycle Engineering, pp. 764 768.

Hunter S.L. and Black T.J. (2007). Lean remanufacturing: A cellular case study, Journal of Advanced Manufacturing Systems, vol. 6 (2), pp. 129-144.

Inderfurth K. and Kleber R. (2013). An Advanced Heuristic for Multiple-Option Spare Parts Procurement after End-of-Production, Production and Operations management, vol. 22 (1), pp. 54-70.

Inderfurth K. and Mukherjee K. (2008). Decision support for spare parts acquisition in post product life cycle, CEJOR, vol. 16, pp. 17-42.

Jacobs F.R. and Chase R.H. (2001). Operations and Supply Management: The Core, McGraw Hill, Boston, MA.

Jacquemont D. et al. (McKinsey and Company). (2014). The Lean Management Enterprise: A System for Daily Progress, Meaningful Purpose, and Lasting Value, Compendium, collected at: mckinsey.com/leanmanagement on 05.04.2018

Jin G. Q., Li W. D. and Xia K. (2013). Disassembly matrix for liquid crystal displays televisions, Procedia CIRP 11, $2^{\text {nd }}$ International Through-life Engineering Services Conference, pp. 357-362.

Jones D.T. and Womack J. (2003). Seeing the Whole: Mapping the Extended Value Stream, The Lean Enterprise Institute, Brookline, MA.

Joseph T.P. (2006). Design a lean laboratory layout, MLO: Medical Laboratory Observer, vol. 38 (2), p. 24.

Kang C. M. and Hong Y. S. (2012). Dynamic disassembly planning for remanufacturing of multiple types of products, International Journal of Production Research, vol. 50 (22), pp. 6236-6248.

Kanikula T. and Koch T. (2011). Methodology of designing disassembly and reassembly processes using lean thinking approach, Advances in Production Management Systems New Challenges, New Approaches, pp. 11-18.

Kellenbrink C., Herde F., Eickemeyer S. C., Kuprat T. and Nyhuis P. (2014). Planning the regeneration processes of complex capital goods, Procedia CIRP 24, New Production Technologies in Aerospace Industry - 5th Machining Innovations Conference (MIC 2014), pp. $140-145$. 
Kin S. T. M., Ong S. K. and Nee A.Y.C. (2014). Remanufacturing Process Planning, Procedia CIRP 15, $21^{\text {st }}$ CIRP Conference on Life Cycle Engineering, pp. 189-194.

Kucher R.J. (2008). A Socio-Technical Study of Lean Manufacturing Deployment in the Remanufacturing Context, Dissertation, The University of Michigan.

Kuper A. and Kuper J. (1985). The Social Science Encyclopedia, Routledge, London.

Kuzu A. (2009). Action research in teacher education and professional development, The Journal of International Social Research, 2 (6), pp. 425-433.

Kvale S. (1996). InterViews: An Introduction to Qualitative Research Interviewing, Sage, Thousand Oaks, CA.

Law J. (2004). After Method: Mess in Social Science Research, Routledge, London.

Liker J.K. (2004). The Toyota Way, McGraw-Hill, New York, NY.

Liker J.K. and Choi T.Y. (2004). Building deep supplier relationships, Harvard Business Review, pp. 104-113.

Lund R. (1983). Remanufacturing: The Experience of the United States and Implications for Developing Countries, CPA/83-17, The World Bank, Washington, DC.

Lundmark P., Sundin E., and Björkman M. (2009). Industrial challenges within the

Remanufacturing System, Proceedings of Swedish Production Symposium, Dec. 2-3, Göteborg, Sweden, pp. 132-138.

Lydecker T.H. (1986). Focus group dynamics, Association Management, vol. 38 (3), pp. $73-$ 78.

Manifesto for a Resource Efficient Europe. (2012). Available at: http://europa.eu/rapid/pressrelease_MEMO-12-989_en.htm

McLaughlin P. and Durazo-Cardenas I. (2013). Cellular manufacturing applications in MRO operations, $2^{\text {nd }}$ International Through-life Engineering Services Conference, Procedia CIRP, vol. 11, pp. 254-259.

Merriam S.B. (1995). Who can you tell from an $\mathrm{N}$ of 1 ? Issues of validity and reliability in qualitative research, PAACE Journal of Lifelong Learning, vol. 4, pp. 51-60.

Modig N. and Åhlström P. (2012). This is Lean: Resolving the Efficiency Paradox, Rheologica, Stockholm.

Monden Y. (1983). Toyota Production System. Industrial Engineering and Management Press, Institute of Industrial Engineering, Norcross, GA.

Morgan D.L. (1992). Designing Focus Group Research: Tools for Primary Care Research, Sage, Thousand Oaks, CA.

Morgan D.L. (1997). Focus Groups as Qualitative Research, Sage, Thousand Oaks, CA.

Morgan J.M. and Liker J.K. (2006). The Toyota Product Development System, Productivity Press, New York, NY. 
Morgan S. D. and Gagnon R. J. (2013). A systematic literature review of remanufacturing scheduling, International Journal of Production Research, vol. 51 (16), pp. 4853-4879.

Mukhopadhyay S.K. and Ma H. (2015). Remanufacturing decisions with uncertain demand and product return yield, International Journal of Revenue Management, vol. 8 (3/4), pp. 274-298.

Mutingi M., Mapfaira H. and Monageng R. (2014). Developing performance management systems for the green supply chain, Journal of Remanufacturing, vol. 4 (6).

O’Donnell J.M. (1988). Focus groups: A habit-forming evaluation technique, Training and Development Journal, vol. 42 (7), pp. 71-73.

Ohno T. (1988). Toyota Production System: Beyond Large-Scale Production, Productivity Press, Portland, OR.

Parker D. et al. (2015). Remanufacturing Market Study, European Remanufacturing Network (ERN), pp. 1-135, available at www.remanufacturing.eu

Parkinson H. J. and Thompson G. (2004). Systematic approach to the planning and execution of product remanufacture, Journal of Process Mechanical Engineering, vol. 218 Part E, pp. 113.

Parry G.C. and Turner C.E. (2006). Application of lean visual process management tools. Production Planning and Control, vol. 17 (1), pp. 77-86.

Pascal D. (2002). Lean Production Simplified: A Plain-Language Guide to the World's Most Powerful Production System, Productivity Press, New York, NY.

Pawlik E., Ijomah W. and Corney J. (2013). Current State and Future Perspective Research on Lean Remanufacturing - Focusing on the Automotive Industry, IFIP International Federation for Information Processing.

Pettersen J. (2009). Defining Lean Production: Some Practical Issues. Linköping University, Sweden.

Phelan A., Griffiths J. and Fisher S. (2000). Pushing worldwide aftermarket support of manufactured goods, Managing Service Quality, vol. 10 (3), pp. 170-177.

Priyono A., Ijomah W. L. and Bititci U. S. (2015). Strategic operations framework for disassembly in remanufacturing, Journal of Remanufacturing, vol. 5 (11).

Robotis A., Boyaci T., Verter V. (2012). Investing in reusability of products of uncertain remanufacturing cost: The role of inspection capabilities, International Journal of Production Economics, vol. 140, pp. 385-395.

Rother M. and Shook J. (2003). Learning to See: Value Stream Mapping to Create Value and Eliminate Muda, The Lean Enterprise Institute, Brookline, MA.

Seitz, M.A. and Peattie K. (2004). Meeting the closed-loop challenge: The case of remanufacturing, California Management Review, vol. 46 (2), 74-89.

Seliger G., Kernbaum S. and Zettl M. (2006). Remanufacturing Approaches Contributing to Sustainable Engineering, Gestao and Producao, vol. 13 (3), pp. 367-384. 
Shadish W.R., Cook T.D. and Campbell D.T. (2002). Experimental and Quasi-Experimental Designs for Generalized Causal Inference. Houghton Mifflin, Boston, MA.

Shah R. and Ward P.T. (2007), Defining and developing measures of lean production, Journal of Operations Management, vol. 25, pp. 785-805.

Slack, N., Chambers, S., \& Johnston, R. (2010). Operations Management. Harlow: Pearson Education Limited

Steffen W., et al. (2015). Planetary boundaries: Guiding human development on a changing planet, Science, vol. 347 (6223), pp. 1-16.

Steinhilper R. (1998). Remanufacturing - The Ultimate Form of Recycling, Fraunhofer IRB.

Sugimori Y., Kusunoki K., Cho F., and Ushikawa S. (1977). Toyota production system and Kanban system Materialization of just-in-time and respect-for-human system, vol. 15 (6), pp. 553-564.

Sundin E. (2006). How can remanufacturing processes become leaner?, Proceedings of $13^{\text {th }}$ CIRP International Conference on Life Cycle Engineering, Leuven, Belgium, May 31-June 02, pp. 429-434.

Sundin E. and Bras B. (2005). Making functional sales environmentally and economically beneficial through product remanufacturing. Journal of Cleaner Production, vol. 13 (9), pp. 913-925.

Sundin E. and Lee H.M. (2011). In what ways is remanufacturing good for the environment?, Proceedings of EcoDesign 2011 International Symposium, p. 551.

The Productivity Development Team. (1999). Cellular Manufacturing: One-Piece Flow for Workteams, Productivity Press, Portland, OR.

United Nations (UN). (2015). Sustainable Development Goals, available at http://www.un.org/sustainabledevelopment/sustainable-development-goals/

Van Nunen Jo A.E.E. and Zuidwijk R.A. (2004). E-enabled closed-loop supply chains, California Management Review, vol. 46 (2), pp. 40-54.

Wang X. and Chan H. K. (2013). An integrated fuzzy approach for evaluating remanufacturing alternatives of a product design, Journal of Remanufacturing, vol. 3 (10).

Wei S., Tang O. and Sundin E. (2015). Core (product) Acquisition Management for remanufacturing: a review, Journal of Remanufacturing, vol. 5 (4).

Womack J. and Jones D. (2003). Lean Thinking: Banish Waste and Create Wealth in Your Corporation. Simon and Schuster, New York.

Womack J.P. and Jones D.T. (2007). Lean Solutions: How Companies and Customers Can Create Value and Wealth Together, Simon \& Schuster, New York.

Womack J.P., Jones D.T., and Roos D. (2007). The Machine that Changed the World: How Lean Production Revolutionized the Global Car Wars, (New ed. of 1990 edition), Simon \& Schuster, New York. 
Wu Y., Li W. and Yang P. (2015). A Study of Fatigue Remaining Useful Life Assessment for Construction Machinery Part in Remanufacturing, Procedia CIRP 29, $22^{\text {nd }}$ CIRP conference on Life Cycle Engineering, pp. 758-763.

Yin R.K. (1994). Case Study Research Methods: Design and Methods, 4th ed., Sage, London.

Zhang H., Liu W., Dong Y., Zhang H. and Chen H. (2014). A method for pre-determining the optimal remanufacturing point of lithium ion batteries, Procedia CIRP 15, $21^{\text {st }}$ CIRP Conference on Life Cycle Engineering, pp. 218-222.

Zhou S. X. and Yu Y. (2011). Optimal Product Acquisition, Pricing, and Inventory Management for Systems with Remanufacturing, Operations Research, vol. 59 (2), pp. 514 521.

Zhou X., Ke Q, Song S. and Liu M. (2014). An Evaluation Method Based on Mechanical Parts Structural Characteristics for Proactive Remanufacturing, Procedia CIRP 15, $21^{\text {st }}$ CIRP Conference on Life Cycle Engineering, pp. 207-211.

Östlin J. and Ekholm H. (2007). Lean production principles in remanufacturing - A case study at a toner cartridge remanufacturing, Proceedings of IEEE International Symposium on Electronics and the Environment, Orlando, FL, May 7-10.

Östlin J., Sundin E. and Björkman M. (2008). Business drivers for remanufacturing, In The Proceedings of $15^{\text {th }}$ CIRP International Conference on Life Cycle Engineering, The University of New South Wales, Sydney, Australia, 17-19 March, pp. 581-586.

Östlin J., Sundin E., Björkman M. (2009). Product lifecycle implications for remanufacturing strategies, Journal of Cleaner Production, vol. 17 (11), pp. 999-1009. 


\section{APPENDED PAPERS}




\section{Appended Papers}

The appended papers associated with this thesis have been removed for copyright reasons. For more details about these see:

http://urn.kb.se/resolve?urn=urn:nbn:se:liu:diva-147875 
